\title{
2. A retrospective of the information systems discipline in Australia
}

\author{
Roger Clarke \\ Xamax Consultancy Pty Ltd \\ Canberra, Australia
}

\begin{abstract}
Information systems (IS) emerged as a discipline in the 1960s. It has struggled to define itself, its scope and its relationship with its neighbouring disciplines in the computing and management arenas. Despite that, it has grown into a diverse and busy community. The discipline in Australia numbers some 700 people, and it has had impacts on the international stage. This chapter charts key events in its first four decades, identifies what appear to the author to be the key themes, provides a body of references for future historians to consider in greater detail and from other perspectives and raises questions for the future.
\end{abstract}

\section{Introduction}

The IS discipline has mostly been too concerned about ensuring its future to spend much time celebrating its past, or even understanding it. As pioneers retire, however, the time has come to consolidate sources and memories and provide some historical background to this vibrant but often troubled field.

Research into the discipline's birth led to 1965 and 1967 as the most tenable start dates. The analysis reaches beyond 1995 only selectively. This is partly because of the scale of the undertaking, and partly because lack of perspective makes it much more difficult to write convincingly about 'recent history' than about 'ancient history'. For further comments on author bias, see the acknowledgements.

A history can be approached from a variety of directions. Because it is something of a 'trail-blazing' exercise, this chapter is intentionally eclectic. It blends (or perhaps muddles) the approaches of the chronicler (Who did what when?), the historian of ideas (Where were concepts, models and theories appropriated from? What scope has been evident? Which topics have been important? Which propositions were debated?) and the political historian (What power bases existed? What skirmishes were fought? Who won?). Little time is spent on historiography or critical thinking (Who wrote what, with what biases, and for 
what purpose?). First, we need some sources. Only then can the battle to own history begin.

The author's own perspectives and biases regarding the scope of the IS discipline will become apparent progressively through the chapter, but two aspects need to be addressed at the outset. Rather than beginning with a discussion about what IS is and what it should be, this chapter sets out with the pragmatic approach that 'IS is what IS does'. Reflection on the rich and at times tumultuous debates about those questions belongs elsewhere. The second limitation is that the traditions with which the author is most familiar are those of Australian IS, US management information systems (MIS), UK IS and information management (IM) and Wirtschaftsinformatik in German-speaking countries (which is translated most appropriately as 'business information systems'). These provide ample evidence, firstly, of different flavours but secondly of a measure of unanimity about the discipline's scope in action, and the matters that, at any given time, have been proper topics to be considered by the discipline's members.

The research method adopted was based heavily on secondary research, starting with the author's own substantial archives dating from 1970, followed by searches for relevant published resources. The modest literature that was uncovered is listed in the bibliography in Clarke (2007). Information from publications was supplemented with face-to-face interviews with a number of key players during the early years and e-mail exchanges and telephone conversations with a substantial number of people - in Australia and overseas. Many of these discussions resulted in further references that needed to be reviewed. The acknowledgements section lists the individuals on whom the author has placed greatest reliance. The now-compulsory 'web trawl' delivered some hits of consequence. Relevant resources are also listed in Clarke (2007). The intended review of IS departments' sites for historically relevant material was not undertaken, because the sampling that was performed suggested that there were more promising avenues in which to invest the available time. The only formalised departmental histories that were unearthed were Greig and Levin (1989) regarding computing at Caulfield/Chisholm (1965-88), Dreyfus (2004) regarding the University of Melbourne's IS department (1994-2004) and Burrows (2006) regarding the same university's accounting department (1925-2004).

The 'IS-in-Oz' team reviewed and provided substantial feedback on the proposal in March 2005, on a sketch in May 2005, on an interim report in November 2005 and on a draft in January 2006. The version of May 2006 was released with a request for comment sent to about 40 senior members of the discipline in Australia and overseas. This elicited important feedback, which has been reflected in this version. An article-length version was extracted and published (Clarke 2006). 
The chapter begins by considering the intellectual origins of the IS discipline. Building on this foundation, key events are identified that are associated with the establishment of the discipline - overseas and in Australia. The development of the discipline is then traced, using a variety of metrics. The later parts of the chapter identify some key themes, of a political and an intellectual nature.

\section{Origins and nature of the IS discipline}

The foundations of IS can be traced back to the late nineteenth and early twentieth-century rational-management stream of thought, associated with Fayol and Taylor. Although usually interpreted as being about efficiency in the use of physical resources through understanding of the 'time and motion' of agents, the movement is reinterpreted easily as also being about the use of information. Drucker (1968) included a large section on what he called the knowledge economy' (which would currently be referred to as 'the information economy'). Drucker (1968:328) argued that 'the idea that knowledge, systematically acquired, could be applied systematically to work is no more than 200 to 250 years old', and first occurred in tool makers and tool designers in the eighteenth and early nineteenth centuries, who laid the foundation for the Industrial Revolution.

Automated equipment - in particular, punched-card handling devices - were in use in large-scale applications at the very beginning of the twentieth century, in particular for the US census (for example, Kistermann 1991). The invention, articulation, application and rapid improvement of electro-mechanical and then electronic computers in the period 1935-50 is well documented (for example, Campbell-Kelly 2003; Norberg 2005). These initiatives were motivated by the processing of ephemeral data into significant results, rather than what we would now call data management. Technologies to provide permanent storage quickly came to be seen as an important adjunct to computation, and the complex of technologies needed to support what became computer-based IS quickly emerged.

The use of electronic computers for the processing of administrative data brought a substantial impetus to the emergence of the IS discipline. Applications of this kind began simultaneously in the United Kingdom and the United States in 1951, with Leo at the Lyons Tea Company, and Eckert and Mauchly's Univac 1 at the US census (Caminer et al. 1998; Land 2000b; Johnson 2006). The first installation of a computer in a US company expressly for administrative purposes appears to have occurred only in 1954, for payroll at General Electric in Louisville, Kentucky (Mason 2005).

To extract a comprehensive history of the early years of business applications of computing, it is necessary to read beyond the substantial US literature on the subject. Many US publications subscribe to the myth that very little of consequence happened outside the United States, and they merely footnote German and particularly British work, even though it was vital from the 1930s 
into the 1960s. On the other hand, the tempo in the United States picked up very quickly, as banks and airlines recognised opportunities, and even more quickly after the emergence of computer architectures designed for business applications - particularly the IBM 360 series from 1964. From about 1960 onwards, US energy dominated innovation in information technology (IT) in Australia, as elsewhere.

The emergence of the IS discipline was in historical terms brisk, but to an observer at the time it would have appeared laboured and wayward. It appears to have followed somewhat different paths in various countries and regions, with distinct flavours discernible in the United States, the United Kingdom, Germany, Scandinavia and Australia. The myopia of the author-and of English-language cultures generally-makes it likely that critical ideas from other countries have been overlooked, or inaccurately attributed.

Differences also occurred within countries, particularly those of substantial geographical size. The term 'the tyranny of distance' (coined by Australian historian Geoffrey Blainey in his 1966 book of that name) might seem quaint to post-Internet generations, but it afflicted countries the size of Australia, Canada and the United States. During the early years of the IS discipline, with no coordinative mechanisms such as an information infrastructure any more sophisticated than the voice-only services over the Public Switched Telephone Network (PSTN) and textual data over the telegraph and telex networks, and with no accreditation panels, no curriculum committees, no textbooks, few conferences and relatively high airfares, there was ample scope for strong, energetic and visionary individuals to have significant local, regional and national impact.

It was natural that the new interest in information would draw on existing disciplines and professions for which data and their processing were already an interest, and on emergent disciplines that were adopting new approaches made feasible by the new technology. The dominant strands appear to have been accounting and the emergent computer science, together with threads arising from a range of other sources. The following were of particular importance.

- Organisation and methods (O\&M), a branch of industrial engineering that applied a form of 'rational management' to organisations' internal operations. This was influential particularly in the United Kingdom, and in some areas of Australia.

- Operations management - although this was far less influential in Australia than it was in the United States.

- Operations research, as it developed in the United Kingdom and the United States during World War II, and its applications in the business arena as management science and decision sciences. Particularly influential authors were Simon (1960) and Miller and Starr. 
- Management accounting - particularly Anthony (1965) and Prince (1966, 1970). Similarly traceable to Taylorism and industrial engineering, this approach focuses on applications of micro-economics that are useful within the organisation, measurement schemes to enable the discovery and analysis of exceptions and ways to manage measurements and communicate them to the managers who need them.

- Systems thinking, which drew originally on von Bertalanffy and Boulding and the Society for General Systems Research in the United States from the mid-1950s onwards (Mason 2005), Emery, Churchman, Jay Forrester, and Katz and Kahn (1966); and in the United Kingdom von Bertalanffy in 1950, and later Peter Checkland. Closely related to this movement was cybernetics, as pioneered by Norbert Wiener, further developed by Ashby and applied by Stafford Beer. This focused on the feedback and control aspects of systems. There was much interest in these bodies of theory in Continental Europe as well, centred on the International Institute for Applied Systems Analysis (IIASA) conferences in Schloss Laxenburg, south of Vienna. The emphases and patterns of development on the two sides of the Atlantic, and within Continental Europe, were rather different, and no history has been located to date that integrates them.

- Socio-technical systems. This thread developed in the United Kingdom from the 1950s onwards - initially at the Tavistock Institute - and was adopted and extended particularly in Britain and Scandinavia. It represented a reaction against the reductionist thinking inherent in the previous strands, and resulted in (sophisticated) mechanistic designs: 'If a technical system is created at the expense of a social system, the results obtained will be sub-optimal' (Mumford 2006, attributed to the Tavistock Institute). The soft-systems school of thought followed. Publications that documented and consolidated this movement included Mumford and Banks (1967), Bjorn-Andersen (1980), Checkland (1981), Mumford (1983) and Wood-Harper et al. (1985).

- Management theory placed expectations on the new and expensive technology. Drucker was particularly influential, as were Ackoff and Likert, and Macfarlan, and Scott Morton (1971) at the Harvard Business School. A range of what could be called 'thinking manager's gurus' had substantial influence on DP/IS/IT managers, including EDP Analyzer (later I/S Analyzer), Dearden, Auerbach, Infotech 'State-of-the-Art' Reports and James Martin. Their impact on IS academics was less substantial, but Martin in particular provided syntheses of material that were much used as IS textbooks.

Beyond the intellectual sources were those dictated by pragmatism. The application of computers to administrative, commercial, industrial and government purposes required the development of software. The necessary rapid production of new software developers depended on the expression and 
structuring of know-how into what would now be called 'codified knowledge' about what came to be called analysis, design and programming. From 1967 until about the mid-1980s, this practical need had a substantial impact on the conception of the scope of the IS discipline. Since then, applications development has drifted away from the mainstream of IS - and IS from it. Programming has been reduced to an industrial skill, and design has become either the independent, cognate discipline of software engineering or a substantial component of the adjacent discipline of computer science - or both. It is unclear which discipline 'owns' analysis, if any. To many IS academics, the perspective typified by the Institute of Electrical and Electronic Engineering (IEEE) is far too narrow and mechanical, with its reductionist conception of systems analysis as 'requirements engineering'.

As the frame within which the remainder of this chapter is developed, some clustering of the themes and topics can be suggested, as follows.

- Technology as enabler and driver, including computers, electronic data processing (EDP), applications, applications development, the software development life cycle (SDLC), the systems life cycle (SLC), computer usage, usability, technology adoption and impediments to adoption.

- Organisations, as the primary context within which information systems are developed and operated, and for whose purposes they are applied, including organisational behaviour, requirements elicitation, business process analysis, usability, technology adoption and impediments to adoption.

- Systems thinking, including O\&M, GST and cybernetics leading from SDLC to SLC, socio-technical theory, soft-systems methods, incorporation of human factors, usability, adoption and merging with human behaviour and communications into semiotics and perhaps ontological foundations.

- Business school thinking, including operations research (OR)/management systems (MS), management accounting, controls and auditing, management of DP/IS/IT/IC\&T, information management, usability and adoption.

- Data and information management, including database management systems (DBMS), data modelling, data dictionaries, information resource dictionary systems (IRDS) and, later, the absorption from librarianship of key concepts about meta-data.

It is stressed that this clustering is a clumsy classification, not a clean taxonomy. As evidenced by the appearance of such terms as 'adoption' in multiple clusters, there was continual cross-feeding and co-evolution of thinking. Particularly during the formative years, the process and the product were highly eclectic, as each local leader sought to make sense of the domain and contribute to progress. 


\section{The foundation years overseas}

This section reviews briefly the beginnings of IS in Europe and North America. It is not intended as a contribution to a broad IS history (because that would require much deeper treatment). Its purpose is to provide a backdrop to the early years in Australia.

The dominance of North American contributors in the published literature suggests that the United States was first in the field. The evidence as a whole, however, suggests that the emergence of IS could have been slightly earlier in Europe - and lagged only slightly in Australia. No material has been located at this stage in relation to the early years in Canada. Clarke (2007) provides time-lines of key events in Australia and overseas.

\section{Europe}

Borje Langefors was appointed Professor in Information Processing at the University of Stockholm in 1965. He proposed a theoretical basis for IS based on 'the infological equation $\mathrm{I}=\mathrm{i}(\mathrm{D}, \mathrm{S}, \mathrm{T})$, where I stands for information, D data, $\mathrm{S}$ the recipient prior knowledge as result of the individual's life experience, $\mathrm{T}$ the time, and i the interpretation process' (Shen 2003). His early texts (Langefors 1963, 1966) were translated into English, although it is not easy to judge the extent of their impact on thinking in English-speaking countries. The 'infological equation' is reflected in Mason (2005:14), which refers to information as 'data interpreted within a point-of-view', and in this author's own explanation of information as 'data that has value [that] depends upon context' (Clarke 1992). Both also appear to relate to Wiener's conception of information as 'data that an organisation could employ for the direction of its activities' (Mason 2005). It is in stark contrast with Shannon and Weaver's conception of information as 'a measure of one's freedom of choice when one selects a message'. That works brilliantly when applied to the transmission of data over a noisy channel, but very poorly in the contexts addressed by IS. Scandinavia has also had a long and strong association with the organisation and human behaviour aspects of IS, including from Niels Bjørn-Andersen, who, after completion of his PhD with Enid Mumford in Manchester, returned to Copenhagen in 1972.

In Germany, Wirtschaftsinformatik (roughly translated as 'business data processing' or 'business informatics') emerged within Betriebswirtschaftslehre (roughly, 'business administration') from the late 1950s and was influenced later much by Informatik ('computer science'). The earliest claim that has been found for the establishment of IS is the Institute for Business Organisation and Automation at the University of Koeln (E. Grochla) in 1963. The first German-language doctoral thesis on an IS topic was in 1966 (Peter Mertens); the next in 1968 (Lutz Heinrich). The first chairs in German-speaking countries were at Linz in Austria (Mertens, 1968-69; Heinrich, 1970-2004), then at Karlsruhe, 
Erlangen-Nürnberg, Darmstadt, Muenchen and Speyer. The first full majors were at Wien and Linz in 1974-75, and in the 1980s large schools emerged in Berlin, Köln, Frankfurt-am-Main, Mannheim, Münster, Nürnberg and Saarbrücken. A national conference has existed since 1987. The leading German-language journal has been called Wirtschaftsinformatik since 1990, but was established as Elektronische Rechtanlagen ('electronic computing systems', 1959-72) and, between 1972 and 1990, was named Angewandte Informatik ('applied computing').

Wirtschaftsinformatik has had a sustained and strong orientation towards data processing and software development, with substantial practical work, but also a significant information management stream (Heinrich 1993; Avgerou et al. 1999; Mertens et al. 2002). Patterns in other German-speaking countries have been not dissimilar. Distinctions between the German and other styles are drawn out by this quotation: 'To what extent will Anglo-American researchers adopt the prototypical IS approach being cultivated in Germany and to what extent will German IS research better adapt to the survey-oriented Anglo-American research culture?' (Mertens et al. 2002).

In the United Kingdom, key appointments occurred in 1967: Frank Land at the London School of Economics (LSE) and Peter Keen at the London Business School (LBS). Together with Enid Mumford, already at Manchester, there were now three separate and rather different flavours. A key publication appeared in the same year: The Computer and the Clerk (Mumford and Banks 1967). This greatly influenced the conception and scope of IS in the United Kingdom, which has generally been attuned to a human-oriented interpretation of systems thinking that reflects the intrinsic ambiguity of the contexts in which information is used and IT applied, and the existence of a range of perspectives that need to be factored into analyses. This relatively 'soft' nature was noticeable in the contributions of Ronald Stamper at LSE from 1972, Peter Checkland at Lancaster and later Trevor Wood-Harper. The discipline in the United Kingdom has, however, come to reflect a wide diversity of approaches.

\section{North America}

The history of the IS discipline in North America (and, to a considerable extent, the world as a whole) is associated by many people with the appointment of Gordon Davis to a chair at Minnesota in 1967. The context was accounting within a graduate school of business, but impregnated with systems thinking. The field was described as 'management information systems' (MIS). Mason (2005:21) traces the origins of that term at least as far back as a 1962 book by James D. Gallagher.

Davis had already published an introductory textbook on computers for business students (Davis 1965), but his key intellectual contributions were encapsulated 
in his 'conceptual foundations' text (Davis 1974; Davis and Olson 1984). Davis spent close to four decades at Minnesota, from 1967 to 2004. Many of the people whose doctorates he supervised have also been active supervisors and, by the time of his retirement in 2005, the 'family' had reached the fourth generation and a total count of more than 100 .

The year 1967 also saw the appointment of Bill King at Pittsburgh, who brought an OR perspective, but grafted on from other disciplines as appropriate. MIS was established at the University of California at Los Angeles (UCLA) by no later than 1968, also growing out of accounting, but with a strong 'systems thinking' emphasis (Mason 2005). Dan Couger published on systems analysis and development techniques - also in a manner imbued with systems thinking. Jim Emery published foundation textbooks (Emery 1969, 1971). Macfarlan and Scott Morton at Harvard Business School published on management aspects of IS from the late 1960s onwards.

Banker and Kauffman (2004) note that the journal Management Science started a column on 'information systems in management science' in 1967, edited by Harry Stern, and included IS in the first departmental structure of the journal in 1969. The Society for Information Management (SIM), which has always targeted the needs of the senior IS executive (in contemporary fashion, the chief information officer or CIO), was an important supporter from 1968. The Association for Computing Machinery (ACM), particularly through its Special Interest Group for Business Data Processing (SIGBDP) and The Institute for Management Science (TIMS) also provided support and considerable influence - from the computing and the operations research perspectives respectively. A perspective on the origins and evolution of MIS is in Dickson (1981).

In the United States, MIS has been imbued with a rationalist approach to systems thinking. Rationalism can be 'bounded', but 'satisficing' is still rational. There is limited scope for looseness and soft systems, little attention is paid to contexts that lack a single powerful entity that can dictate a requirements statement, and limited credence is granted to serendipity and what Ciborra called 'bricolage'. Strategically successful IS have to be attributed to intelligent management and cannot be seen to be the semi-accidental result of complex interactions. Tensions between perspectives are in principle capable of being balanced out, but in many cases they are simply overridden in deference to some 'greater good'. The greater good is by definition determined rationally, but from some particular perspective - generally that of the most powerful player or alliance of players.

Clearly, this stark juxtaposition of 'hard US' versus 'soft British and Scandinavian' philosophies in IS is an over-simplification that is subject to many qualifications, particularly in recent years as the level of trans-Atlantic communications, interactions and alliances has increased. In particular, a number of US writers have argued the case for interpretivism - for example, Boland (1978), Lee (1994) 
and Chen and Hirschheim (2004). Nonetheless, the tension between the 'hard' and the 'soft' exists; and it is not infrequent that the distinction is a regional one.

\section{The first $\mathbf{4 0 - 5 0}$ years in Australia}

A retrospective needs to adopt a largely chronological presentation, and to divide the period covered into digestible pieces. One possibility is to apply an interpretation of the phases of the IT, such as that in Table 2.1.

Table 2.1 Information technology history and its implications

\begin{tabular}{l|l|l|l}
\hline & $\mathbf{1 9 4 0 - 8 0}$ & $\mathbf{1 9 8 0 - 2 0 0 0}$ & $\mathbf{2 0 0 0 - 4 0}$ \\
\hline Processor technology & $\begin{array}{l}\text { Grosch's Law: bigger is } \\
\text { more efficient }\end{array}$ & $\begin{array}{l}\text { VLSI/micros: more is more } \\
\text { efficient }\end{array}$ & $\begin{array}{l}\text { Commoditisation: chips } \\
\text { with everything }\end{array}$ \\
\hline Network technology & Star: centralised & $\begin{array}{l}\text { Multi-connected: } \\
\text { decentralised }\end{array}$ & Wireless: ubiquitous \\
\hline Processor interrelationships & Master-slave: control & $\begin{array}{l}\text { Client-server: } \\
\text { request-response }\end{array}$ & P2P: collaboration \\
\hline Organisational form & Hierarchies & Managed networks & $\begin{array}{l}\text { Self-managing } \\
\text { market/networks }\end{array}$ \\
\hline Software and content & Closed, proprietary & Confusion and tension & Open \\
\hline Politics & $\begin{array}{l}\text { Authoritarianism: } \\
\text { intolerance }\end{array}$ & Confusion and tension & $\begin{array}{l}\text { Democracy and frustrated } \\
\text { intolerance }\end{array}$ \\
\hline
\end{tabular}

Source: Clarke, R. 2004, 'Origins and nature of the Internet in Australia', Xamax Consultancy Pty Ltd, viewed 22 March 2007, <http://www.anu.edu.au/people/Roger.Clarke/II/OzI04.html> [at Exhibit 3.7]

Such an interpretation would, however, be unsatisfactory because although technology has been a driver - and even the major driver - it has not been determinative of the development of the IS discipline. This section presents what appear to the author to have been the key events in the emergence of the discipline in Australia, divided into three chunks of time that are proposed as being useful rather than decisive. Mason (2005) uses a related but somewhat different division:

- pre-formation: mid-eighteenth century to 1954 (addressed above)

- gestation: 1954-68 (addressed below)

- birth: 1968-2000 (subdivided below for reasons specific to the Australian context)

- rebirth: 2000 (addressed in the closing sections of this chapter).

\section{Until 1960}

Australia has something of a history in automated computation. In particular, the world's first totalisator - for 'totalling up' wagers, particularly on horse-races, and sharing the pool among the winning bets (and extracting fees and taxes) - was invented in Western Australia by George Julius about 1913 (Bennett et al. 1994). Although this was originally an entirely mechanical system, electrical components were later added. Julius's company enjoyed a world-wide monopoly for some time. 
Later, the fourth electronic digital computer, CSIR Mk 1 (1948-56), was entirely 'home grown' in Australia - at the Council for Scientific and Industrial Research (CSIR) Division of Radiophysics in Sydney (Pearcey 1988:12-19, 160. See also Bennett et al. 1994:15-58, esp. 16-30). Mk 1's successor, CSIRAC, ran from 1956 until 1964 at the University of Melbourne. The University of Sydney's locally designed and built SILLIAC ran from 1954 until 1968, and the university also designed and built SNOCOM for the Snowy Mountains Authority (1960-67). Adapted versions of imported machines ran at the University of New South Wales (UNSW) (UTECOM, 1956-66) and at the Weapons Research Establishment (WRE) (WREDAC, 1956-66). There is a persistent mythology in Australia that the Commonwealth Scientific and Industrial Research Organisation (CSIRO, which succeeded the CSIR in 1949) abandoned investment in computing in favour of cloud seeding. This story is all the more poignant when it is appreciated that the last CSIRO-developed computer, from about 1963-68, was called the Cirrus (Pearcey 1988:66). A recent international perspective on the early years is in Chapter 7, 'Wizards of $\mathrm{Oz}^{\prime}$, in Hally (2005:161-84). The predominant influences throughout this formative period were British rather than American, which derived in considerable measure from John Bennett's work on the earliest machines in the United Kingdom, including the first stored-program computer, EDSAC, at Cambridge.

Pearcey (1988:157) and Bennett et al. (1994:26) identify the first computer conference in Australia as having been held in March 1951 in Sydney, run by the University of Sydney and CSIRO. Bennett et al. (1994:28) cites papers in the Proceedings of an April 1952 conference on automatic computing machines, run by CSIRO, although this could have been a late publication of the papers from the 1951 event.

The second Conference on Automatic Computing and Data Processing was held in June 1957 at WRE (later renamed the Defence Science and Technology Organisation - DSTO) at Salisbury, north of Adelaide. It had three sections, one of which was 'Business applications'. The conference chair, John Ovenstone, contributed a paper on 'Business and accountancy data processing' (Pearcey 1988:47-8). This was only six years after the first commercial use of a computer in the United Kingdom and the first governmental use in the United States, and only three years after the first commercial use in the United States.

Until 1957, the circa-8 computers in Australia were all in universities and the WRE. By 1960, however, there were 34 within government alone and, by 1963, about 80 computers (Pearcey 1988:137, 159) or 'nearly 100' (Bennett et al. 1963:11). Bennett claimed that the count per million of population was on a par with Sweden, West Germany and the United Kingdom, and was exceeded only by the United States, Canada and Switzerland. 
Few of the computers were intended exclusively for research. Commonwealth government agencies-beginning with the Department of Defence and the Australian Bureau of Statistics (ABS) - had installed computers for administrative tasks. In defence, for example, Ovenstone, an immigrant from the United Kingdom, was appointed to the new position of Controller of Automatic Data Processing at senior level (Band 2 SES), and drove the project from 1958 to 1964 (Pearcey 1988:72-4). The organisationally logical way for bureaucracies to integrate programmable computers into their ways of working was to conceive of them as super-tabulators, and manage them in a similar way.

The first Australian companies to install computers are understood to have been the two insurance companies AMP and MLC - both in 1960, nine years after the first in the United Kingdom, and six years after the first in the United States. In interview, Bill Caelli said that BHP had IBM 1401 and 1440 models installed in Newcastle and Wollongong by no later than 1962, and applied them to a variety of operations-management and commercial functions.

\section{From 1960 to 1973}

The Australian National Committee on Computation and Automatic Control (ANCCAC) was formed in 1959, with John Bennett as chair. It appears that the First [Australian computer] Conference was held at the University of Sydney and the University of NSW on 24-27 May 1960 under the chairmanship of Dr. J. M. Bennett of SILLIAC fame' (McDowell 2002). According to McDowell, 43 of the 158 papers at the event were focused on 'commercial applications'.

This was very early in the international history of computing outside the confines of closed military institutions. The first international congress was held only in 1959, in Paris. The International Federation for Information Processing (IFIP) was formed in 1960 - and John Bennett was one of the key instigators of its formation.

Computing was a new field and suffered the classic 'bootstrapping' problem. Very few staff with the necessary background were available for hire - although migrants from the United Kingdom who could claim some relevant background, such as cryptanalysis, were in demand. Tertiary institutions could not yet offer courses, because they had no staff who could develop teaching materials and provide instruction. Agencies depended heavily initially on such training as was available from the suppliers of the technology they had purchased, and on the internal training schemes that they put together. A limited set of design techniques was available at this stage; however, Caelli recalls Fred O'Toole at BHP Newcastle being a strong fan of decision tables in 1963.

The second conference in 1963 included 20 such papers, primarily case-study reports, including one by Ovenstone on the Department of Defence, and others on the Snowy Mountains Authority Stores System, insurance and banking. 
Training within the Commonwealth public sector was formalised as the Programmer-in-Training (PIT) scheme, beginning in 1963 (White and Palfreyman 1963; Bennett et al. 1994:108; ABS 2005; interview with Gerry Maynard in 2005). This 'was oriented toward training staff for establishing and running commercial and administrative applications of computing' (Pearcey 1988:122), and involved 'a full year at about twenty hours per week of class time, and effectively more than twenty hours per week of related private study' (p. 121). The scheme was run at least in Canberra and Melbourne. In Canberra, the Department of Defence ran it for its own staff and the then Commonwealth Bureau of Census and Statistics (CBCS, soon after renamed the ABS) ran it for itself and other agencies. The Postmaster General's Department (PMG) ran the Melbourne courses. Coordination was provided by the Public Service Board (PSB, disestablished in 1987).

The CBCS/ABS variant was what would later be called a 'sandwich course', including 'two ten-week stints of on-the-job training'. In an interview, Gerry Maynard said that the content was about 50 per cent programming and 50 per cent systems analysis and design. The 1965 CBCS syllabus included two languages, FORTRAN and COMPASS (CDC's Assembler), and the 1971 ABS syllabus somehow managed to cram in COBOL as well. 'Exams at the end of the year included a major systems analysis and design exam for which a time was allowed of "up to seven hours if required"' (ABS 2005).

Some hundreds of people entered the industry through these courses, primarily into the Commonwealth Public Service, but with substantial ripple effects into state government agencies and the private sector. This author's professional life in IS began in 1971, when he was hired into the Sydney industrial corporation Wormalds by Neville Clissold, a 1965 PIT scheme graduate.

By the mid-1960s, courses that were the precursors to what became 'computer science' were emerging in various tertiary institutions in various departments, including physics (Sydney), engineering (UNSW) and mathematics (Newcastle). The author and several reviewers were subjected to primitive versions and crippled subsets of FORTRAN about 1967.

In Australia, as elsewhere, the computer science discipline largely avoided applications, particularly those in business and government. This provided space for the emergence of data-processing specialisations and the IS discipline.

In 1965, the Caulfield Institute appears to have established the first specialist department, called Electronic Data Processing (EDP). The foundation staff were John McClelland, Doug Mills, Jack White and Pearl Levin, joined soon afterwards by Peter Juliff, Bob Grant and Gerry Maynard. Trevor Pearcey joined as head of department in 1972. The courses combined instruction about technology with teaching about how to apply it. Programming was a central feature, because all 
applications had to be custom built, few utilities were available and the era of code libraries was yet to arrive (Greig and Levin 1985).

Meanwhile, IS topics were emerging in university accounting departments. These were isolated, and the period was poorly documented. From interviews, it appears that the first mover was Ted Dunn, from 1965 to 1973, at the University of Tasmania, using Algol (interview with Stewart Leech). From the author's personal knowledge, Phil Grouse was offering full units at UNSW by no later than 1968, the purpose of which was to enable commerce students to understand computers, software and their applications, programming languages and software development. At the University of Melbourne, John McMahon and Stewart Leech offered an EDP unit in 1970, but this grew out of earlier fee-paying courses for industry (interview with Stewart Leech in March 2005; Burrows 2006). Interviews have also unearthed mentions of the then Wollongong College of UNSW, and of Douglas V. A. Campbell, of the Monash Accounting Department during the late 1960s.

Sydney and Melbourne were major world cities, and Wollongong was one of the major centres in the then very large steel industry. Hobart's early activity was presumably stimulated by the installation at the Tasmanian Hydro-Electric Commission.

Further Australian Computer Conferences (ACCs) were organised by ANCCAC - the second in Melbourne in 1963 and, in 1966, the third in Canberra (Pearcey 1988:130). Meanwhile, various state-based associations of practitioners emerged during the first half of the 1960s. The early movers were generally well educated and scientific in outlook. The Australian Computer Society (ACS) was formed in 1966 through the federation of those associations.

The PIT scheme was operated by at least the ABS until 1972. In interview, Cyril Brookes said that he arranged for a course to be run in Port Kembla in the late 1960s, to support the BHP steelworks and local industry on which it depended. Beginning in the late 1960s, a transition was begun to several colleges of advanced education (CAEs). For example, the ABS conducted training in conjunction with the Canberra College of Advanced Education (CCAE), with an internal bureau exam. By 1972, Caulfield Institute in Melbourne, Bendigo College and the CCAE were all operating award courses whose origins could be traced to the PIT scheme (Gerry Maynard in interview; Pearcey 1988:121-2; Greig and Levin 1989). Caulfield developed the course into a formal Graduate Diploma in Data Processing, and then expanded into a range of other specialised postgraduate courses.

Internal training courses continued to have their advantages (for example, Fiedler $1969,1970)$, but gradually what would later come to be called 'outsourcing' was applied. For new entrants, courses were provided primarily by universities and CAEs, although training in specific programming languages and software products was offered by suppliers. Universities, CAEs, suppliers and the emergent 
private-sector training companies conducted continuing professional development courses.

The ACS established the Australian Computer Journal (ACJ) in 1967, and for many years also published a second-tier, non-refereed Australian Computer Bulletin (ACB). Until the establishment of the Australasian Journal of Information Systems (AJIS) in 1994, these were the only directly relevant domestic outlets for Australian IS academics.

The ACS also took over the Australian Computer Conferences, and ran well-attended events beginning with the fourth conference in August 1969 and the fifth in Brisbane in May 1972; it then ran the conferences biennially and then annually with the last of the 18 held in 1991 (Bennett et al. 1994:296). By the early 1990s, the computing community had become the IT community, and had splintered into a great many specialist conferences. With that, the attractiveness of a focal event waned. An annual Computing in CAEs Conference also ran from the late 1960s until the late 1980s. The papers presented at these conferences were lightly refereed in comparison with the $A C J$, but the topics were of relevance to an analysis of the preoccupations of the profession and discipline at the time - for example, this author's first paper at the seventh ACC in Perth was entitled 'Top-down structured programming in COBOL' (Clarke 1976).

A measure of the explosion in business applications between the mid-1960s and mid-1970s can be gauged from the once-fraught area of payroll processing. Large government agencies and corporations wrote the earliest payroll applications in the early to mid-1960s. In interview, Caelli recalled using the patch-panel of an IBM 407 in late 1962 to program payroll for IBM Newcastle. In 1971-72, working as a systems analyst for an industrial company, this author had little option but to design and write a payroll application to run on the company's GE405. In 1975, however, working for a shipping company with 400 employees and a Honeywell 2000, there was a choice of several packages, one of which was adapted to satisfy some specific requirements, and converted to run on the company's machine, with little difficulty or delay. In short, the passage from custom-built assembler applications, via custom-built COBOL applications, to a mature market of packaged applications required, for this particular application, little more than a decade. This had substantial implications for the nature of market demand, and hence IS syllabi.

An important step in the maturation of the computer industry was the 'unbundling' of software from hardware. Until IBM's announcement in 1969, computers had been purchased for a single price, with such software included as the supplier could offer. As the sophistication and significance grew, software needed to be priced separately. That in turn led to greater visibility, and what would now be called application programming interfaces (APIs) and 'open 
source', such that specialist software developers could offer add-on and replacement software (for example, Campbell-Kelly 2003).

Although academics in foundation disciplines such as mathematics and physics had played a considerable part in the establishment of the ACS, its primary role quickly became that of a professional association. Its most direct relationship with tertiary institutions was as an accreditation body, assessing the suitability of courses as a basis for professional membership of the society. As Pearcey (1988:131) put it, '[T]he direction of development of the ACS moved away from its early, more academic style to represent the wider interests of [its] new membership more directly.' This encapsulates nicely the way in which the relationship between profession and discipline has seemed frequently to be as much about tension and distance as about mutual respect and cooperation.

The ACS has played an important role in the International Federation for Information Processing (IFIP), whose working groups run important international conferences in the computer science and IS disciplines. Several Australians have been major players in IFIP, including Ashley Goldsworthy as president, Bill Caelli as chair of TC11, Guy Gable as chair of WG 11.2 and similar contributions by others to TC8 and its working groups. Several major IFIP conferences were held in Australia, including the World Congress in 1980, and major TC8 conferences in 1984 and 1988.

By about 1970, IS was becoming a recognisable disciplinary activity within universities. At the University of Queensland, computer science offered a postgraduate diploma in IS, and accounting offered an Honours unit taught by British academic Peter Richards. Ross Jeffery and Ron Weber were in the same University of Queensland Honours class in 1970-72, and both submitted Honours theses on IS topics. Weber's, in 1972, was entitled 'An examination of file structures for information processing systems'. Other institutions active about this time included the New South Wales Institute of Technology (NSWIT, later the University of Technology, Sydney; Philip Stanley) and Queensland Institute of Technology (QIT, now Queensland University of Technology; Alan Underwood).

The author's Honours thesis at UNSW, also in 1972, was on an IS-related management accounting topic. It is noteworthy that, of the strands noted in the origins section of this chapter, almost all were represented in the readings set for the UNSW Management Accounting Honours unit in 1972, which was designed by liberal accounting professor Bill Stewart. The exceptions were O\&M (which had already been covered in undergraduate IS), management theory (represented by Ackoff and Likert, but not yet by Macfarlan and Scott Morton) and socio-technical and soft-systems thinking (which were yet to make their impact in Australia, and in any case did not fit well with the then strongly numerate and rational patterns of management accounting and the emergent 
IS/MIS discipline). The author has no record or memory of the Minnesota School having an influence at that stage, although it did soon afterwards; nor is this author aware of contact between the Queensland and UNSW schools until after 1972. Ross Jeffery did, however, move to the latter in 1975.

Although much of the intellectual basis of the IS discipline in Australia was provided by Americans, the materials used for teaching professional knowledge to undergraduates during the foundation years were much more eclectic. In this author's experience, some came from technology suppliers (mostly American, but some British), much was home grown and at least as many texts and articles had UK origins as US ones. In interview, Caelli referred to early systems analysis courses deriving from the Leo experience in the United Kingdom, and Cyril Brookes bemoaned the lack of appropriate textbooks as late as the end of the 1970s.

It is instructive to compare developments in IS with the emergence of computer science. Although computer science units emerged from the late 1950s in departments of physics, electrical engineering, mathematics and statistics, the growth was very slow until the mid to late 1960s. In 1963, there were 18 full-time staff in eight universities, with only John Bennett occupying a chair (Bennett 1963:14). According to Pearcey (1988:103-18), departments of computer science emerged in the following order: Basser at the University of Sydney (out of physics, John Bennett, about 1956 and independent from 1959); Adelaide (John Ovenstone, 1964); UNSW (out of electrical engineering, M. W. Allen, emergent from 1965); Monash (initially information science, C. S. Wallace, 1968); Queensland (G. A. Rose, 1969); Melbourne (Peter Poole, 1972); and Tasmania (Arthur Sale, 1974).

Offerings in computer science in most cases migrated from postgraduate diplomas back to final-year undergraduate, eventually expanding into full majors. It appears that the first full computer science majors became available only in 1975, at the Universities of Melbourne and Tasmania (Bennett et al. 1994:152). Information systems units were well established by then, because demand had ensured that many universities offered IS service units, at least the Universities of New South Wales and Tasmania already offered IS majors and others were emergent, and many CAEs and institutes offered postgraduate diploma courses in various areas of computing, including IS. As Pearcey (1988:116) put it, '[I]n some institutions special courses which concentrate upon administrative uses in computing are offered outside the formal computing departments and centres.'

It was to prove crucial that, by the end of 1973, there were at least six professors of computer science, but none of IS. 


\section{From 1974 to 1987}

The development of computer science was explosive. Sufficient full professorships existed, and more were established. The Australian Computer Science Conference (ACSC) was established in 1978, the Australian Association of Professors of Computer Science (AAPCS) was formed in 1982 and the total academic staff-count more than trebled from 1981 to 1990 - to 388 (Sale 1994). By 1988, there were about 1200 computer majors graduating from departments of computer science or similar, in 17 universities and 22 CAEs (Pearcey 1988:124). The political development of the IS discipline, on the other hand, lagged computer science by more than 15 years, hamstrung by the absence of the political power associated with a department and at least one full professor.

Only in 1974 was the first professor of IS appointed (Cyril Brookes) and the first university IS department formed (at UNSW). This was almost a decade after the CAE sector had started to form departments of computing and data processing. The move was a strategic measure by UNSW's Dean of the Faculty of Commerce and Economics, Athol Carrington. The Australian Financial Review reported at the time that the appointment was the first at an Australian university specifically directed towards the financial and managerial applications of computers and operations research technology' (McGregor 1974).

In interview in mid-2005, Brookes said that, in the mid-1970s, there was no body of knowledge and no clear foundation on which to build it. The SDLC and DBMS had emerged in the late 1960s, but it required years of experimentation and refinement before they matured and merged into structured analysis and design. Only then was a framework available for which project management could be overlaid, as a basis for teaching and research. In addition, no prior student knowledge of technology could be assumed, so a considerable amount of time had to be spent on introductory computing topics. Brookes suggested that UNSW was an innovator in placing data analysis in an entry unit in the mid to late 1970s, to establish disciplined thought at an early stage. Many institutions had great difficulty breaking the road-block presented by long-standing and powerful competitor departments that prevented IS from occupying more than one narrow thread in first year.

In interview, Gerry Maynard indicated that curriculum development at Caulfield was largely insular, with little input coming in from overseas. Course committees were more effective in communicating what needs industry had. Ron Weber also considered that the published curricula that progressively emerged - primarily in the United States but also in the United Kingdom — while informative, were not well fitted to the Australian context. They were comprehensive and oriented towards either computer science or the specifically US form of graduate schools of business. Because limited time was available 
within IS service units, topics had to be selected and integrated into local course environments, particularly 'accounting information systems'.

A major report on computer-education needs and resources was published in late 1975 (Smith and de Ferranti 1975, usually referred to as the Barry-Barry Report). The report, for the Australian Commission on Advanced Education, presaged the rapid growth in small business computer systems and packaged software.

Demand for IS graduates, and hence the growth of the IS discipline, were driven by corporate endeavours to exploit the use of computing by individuals. This was associated with the explosion in the accessibility of inexpensive devices beginning in 1975 (particularly the Apple II in 1977, Visicalc in 1979 and the IBM PC in 1981) and lasting to about 1995. This was reinforced by the rapid improvements in the interconnectivity of PCs from about 1985 (internally) and 1995 (externally).

About 1975, postgraduate contributions beyond Honours began to emerge. This author's Masters sub-thesis, completed at UNSW in 1976, appears to have been one of the first. Its title, 'The implementation of functional system design and development techniques in a COBOL environment', is indicative of maturity in the software development phase of IS, but not of any broadening out towards what IS was to become.

The late 1970s saw progress internationally, with the first IS-specific refereed journals in 1977 (MIS Quarterly and Information \& Management), the conversion of the long-standing IS journal Database to refereed form in 1979 and the first International Conference on Information Systems (ICIS) in 1980. (Because the author was in professional positions in London and Zürich from 1977 to 1982, his archives and memories of the IS discipline of that time are limited.)

From about 1980, as skills became more structured and teachable, and as large volumes of product-related training became necessary, the vocational-education sector and particularly colleges of Technical and Further Education (TAFE) became active in the IT area. A number of private colleges also emerged, a few of which have been active for an extended period.

The first local textbook appears to have been Brookes et al. (1982). It had few competitors, and had some success overseas as well. The orientation in universities was most commonly towards application software development, particularly analysis and design, in order to draw the focus of development away from programming and achieve relevant and effective information systems. There were parallel developments in IS management, and in decision support. Over time, information management became a distinguishable body of knowledge, and intellectual relationships developed with library science. 
After UNSW's pioneering move, other early movers at departmental level were QIT and NSWIT. There was, however, a long delay before recognition of the discipline was sufficient for further full professorial positions to be created. The next professorship did not emerge until 1981, and even then Ron Weber's position at the University of Queensland (1981-2004) was throughout a joint accounting and IS role. The next appointments were not until 1988 (Bob Galliers at Curtin); in 1990, at UNSW (Ross Jeffery), the University of Queensland (Maria Orlowska), the University of Technology, Sydney (UTS) (Igor Hawryszkiewycz), and Monash (David Arnott, Peter Juliffe and Phillip Steele); in 1991, at UNSW (Michael Lawrence); and in 1992 at the University of Tasmania (Stewart Leech). Monash University, when it absorbed Chisholm in 1988, took over the mantle from QIT/QUT as the largest concentration of computing-related academics in Australia. Snapshots of IS professorships in Australia are provided in Appendix 2.1 .

Arguably, the first doctorate completed by an Australian in IS was that by Ron Weber, supervised by Gordon Davis, and awarded by the University of Minnesota in 1978. The first IS doctorates completed in Australia appear to have been those by Errol Iselin in 1982 and Iris Vessey in 1984, both at the University of Queensland and both supervised by Weber. Ross Jeffery completed his at UNSW in 1986 under Cyril Brookes, and Rick Watson completed his at Minnesota in 1987 under Gerardine DeSanctis. Appendix 2.2 lists the IS PhDs known to have been completed by Australians, from the first in 1978 until 1995. For most Australian IS academics, however, the first opportunity to become acquainted with American and European professors was created by the ACS/IFIP TC8 conferences in Sydney in April 1984 and March 1988.

The prior computer-usage experience of first-year students changed significantly from year to year during this period. The author conducted surveys of first-year accounting students from 1984 until 1992. The first commoditised personal computing device (the Apple II in 1977) and the accompanying first spreadsheet modeller (Visicalc) had laid the foundations, but it took a further 15 years - until the early 1990s - for matriculating students entering Australian business faculties to have sufficient exposure that computing basics could be switched from core to remedial mode. Although entrants to IS courses tended to have had greater exposure to IT than had entrants to business courses, 'introduction to computing' groundwork consumed a considerable proportion of the limited available curriculum space in IS until at least the end of the 1980s.

Meanwhile, between the 1970s and the 1990s, there was considerable growth in the proportion of matriculants continuing to post-secondary studies, and then in the numbers of mature-age candidates returning to post-secondary education - at bachelor and postgraduate levels. During the next decade, a 
considerable proportion of these undertook at least some IT-related study, including IS.

By the mid to late 1980s, a moderate collection of textbooks was emerging to encapsulate the mainstream knowledge in the discipline and facilitate its transfer to the next cohorts of students. Clarke (1987) provides a snapshot of one person's assessment of the list of books that should have adorned the computing professional's bookshelf' at the time.

\section{Since 1988}

The orientation in universities was - and continues to be - towards theory and the intellectual aspects of disciplines. There was a tension between this orientation and the government's wish to produce rapidly increasing numbers of graduates. The government wanted people whose secondary-school performance had been lower than the highest rank to emerge as graduates who were familiar with the new and rapidly mutating hardware and software technologies, and who had an understanding about what to do with them.

The needs of these more practically oriented candidates were serviced mostly by the institutes of technology and CAEs, which had existed since the previous sectoral reorganisation in the mid-1960s. The CAE sector performed a role midway between the abstract, education-oriented work within universities and the concrete training provide by technical colleges. This resulted in a wide array of courses and units relevant to IS. On the other hand, staff in CAEs had longer contact hours (typically 13-16 rather than seven-eight hours a week), they were not funded to perform research and they had limited opportunity to attract external research funding. The CAEs accordingly provided a home to only a minority of the research-oriented academics in the IS discipline, and there was something of a cleft within the still-emergent discipline.

Rather than focusing its attention and resources on the CAEs, the government chose to demolish the highly valuable distinction between institutions with industry-oriented mission statements and those with primarily academic orientation. The restructuring of the tertiary education sector, initiated by the Labor government in 1987, has been highly disruptive and massively wasteful. The diktat saw the disestablishment of the 40 or so CAEs and 25 other smaller elements and the amalgamation of their operations variously into the existing 19 universities and six some-time institutes of technology, or into one of about 15 new combinations (AVCC 2004). Substantial and vital differences among the missions of the various types of institution were ignored, and remain confused even now. The previously more industry-oriented institutions came to perceive substantial roles for themselves in research and sought better access to research funding. The sector has been in more or less continuous flux since, driven by a culture of interventionism by the relevant agency, most recently the Department 
of Education, Science and Training (DEST). Flurries of additional administrative responsibilities have been imposed on universities, drawing resources away from teaching and research.

Among other things, the 1990s saw the death of the concept of a university as a collegial undertaking, and the imposition of managerial rationalism. To a considerable extent, profitability and return on investment are now the measures of worth of universities' senior executives. Academic ideals of all kinds - such as the pursuit of knowledge, freedom to research, open access to research outcomes and tenure - have become constraints rather than objectives. Pluralism has been deeply compromised by 'mission statements', 'key performance indicators' and the simplicity of 'the bottom line'. Oxford, Bologna and Tübingen wept; the Harvard Business School exulted.

Meanwhile, the per-student funding of all institutions was progressively slashed. Institutions were forced to seek funding from external sources, predominantly by attracting foreign fee-paying (FFP) students onto their campuses or into their existing distance education offerings, or by earning revenue from foreign campuses in excess of the costs involved in running or participating in them. Many strategic manoeuvres have been attempted-many in amateurish fashion - with the result that a number of universities are in dire financial straits. Multiple experiments with strategic alliances have been tried (including the Group of Eight, Innovative Research Universities Australia, Open Universities Australia, New Generation Universities and Regional Universities), most with limited impact. The dislocation arising from this massive change in business models is still being felt, many institutions have worrisome exposure to the vagaries of the education export market and the quantity of research is less than it might otherwise have been. Meanwhile, with staff-counts down and student-staff ratios much higher than they were two decades ago, it is unlikely that the quality of teaching has improved.

In 1990-92, a government review was undertaken of what were styled the 'computing studies and information sciences disciplines'. It was referred to popularly by the name of the committee chair, Hudson (1992). The submissions by the ACS and the ANU utilised a graphic, prepared by this author, which sought to convey the scope of IS and its relationship to the other relevant disciplines (Figure 2.1). Information systems was depicted as occupying vital space between the technical and business disciplines, encompassing a range of applied and instrumentalist topics, and interacting closely with many other disciplines and sub-disciplines. During the intervening 15 years, the topics might have changed somewhat, but the general framework arguably still provides a reasonable representation of the relationships. 
MODEL SHOWING INFORMATION TECHNOLOGY AREAS AND DISCIPLINES AND INTERFACES WITH OTHER PROFESSIONAL BODIES

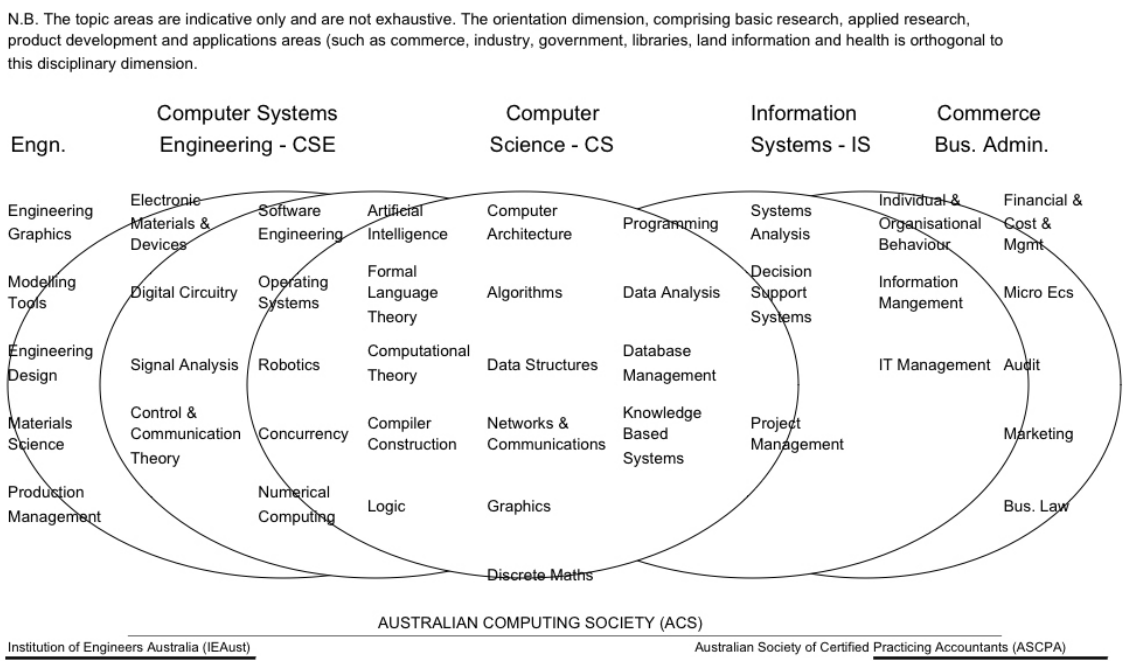

Figure 2.1 Location of the IS discipline, as perceived in 1991

Source: Australian Computer Society (ACS) 1992, Report of the Task Force on the ACS Towards 2000, Australian Computer Society, Sydney, Attachment 5.

Well into the 1980s, communications within the discipline in Australia were informal and somewhat haphazard. An early step to draw the scattered individuals and groups together was the development of a directory (Clarke 1988, 1991; Gable and Clarke 1994, 1996). This was merged, together with the North American directory (Davis and DeGross 1983) and the European directory (Bjørn-Andersen and Hansen 1993), into the world-wide online directory that was launched by Dave Naumann at Minnesota in 1995.

A critical initiative was the establishment of a regular national conference, the Australian Conference in Information Systems (ACIS). The first was held at Monash in 1990, chaired by Ross Jeffery, and it has run annually since then. During the first few years, the standing committee comprised Ross Jeffery, Ron Weber, Roger Clarke, Peter Weill and Igor Hawryszkiewycz. The committee then migrated to the ICIS pattern of rotating membership involving recent, current and upcoming organising and program committee chairs.

The mid-1990s saw maturation of the IS discipline at the international level. As the Internet was grasped as an opportunity for international communications and publication, the ISWorld mailing list and web site were established-both in 1994. The international Association for Information Systems (AIS) was also formed in that year. The regional forums (the Pacific Asia Conference on Information Systems, PACIS, from 1993; the European Conference on Information Systems, ECIS, from 1993; and the American Conference on Information Systems, 
AMCIS, from 1995) provided a broader geographical frame for ACIS. Australians were active contributors to ISWorld, the AIS and the directory project, and to ECIS, PACIS, AMCIS and other international conferences.

Meanwhile, Rob McGregor established the national specialist journal, the AJIS, in 1994 at Wollongong University. Liaison among professors and departmental heads had been emergent, and was formalised through the ACPHIS in 1995. An ISWorld page for Australia was established by this author in 1996. A chapter of AIS was established in 2001.

The discipline continued to consolidate and expand through the second half of the 1990s, but it has suffered a substantial set-back since 2000. A later section of this chapter considers some aspects of this, but to a large extent the focus is the period 1965-95.

The early sections of this chapter have provided a largely chronological presentation of the development of the discipline. The remaining sections adopt a thematic structure, picking out aspects of the story that appear to have been of particular significance.

\section{Drivers and scope}

Critical among the questions addressed in this section are where the heartland of the discipline is to be found, and why. There can be little doubt that technology has been the biggest driver of change, qualified by organisational concerns. Whether technology is more than just a driver-and perhaps the core of the IS discipline - is considered progressively through the remainder of the chapter and is also reflected on in Chapter 12 of this book.

This section enumerates and briefly describes important aspects of what IS has done, and is doing, paying particular attention to changes in flavours over the years. Inevitably, the themes and the manner in which they are presented reflect this author's perspective on the discipline; it has, however, been cross-checked for completeness and structure against Culnan (1986, 1987), Land (1992), Barki et al. (1993), Avgerou et al. (1999), Pervan and Cecez-Kecmanovic (2001), Galliers and Whitley (2002) and Banker and Kauffman (2004).

Beginning slowly in the 1950s, accelerating through the 1960s and exploding in the 1970s, computers were being installed and organisations were beginning to spend considerable sums of money on them. They needed people to apply them and the resources committed had to be managed in order to contribute to the needs of the organisation. Initially, the opportunities were perceived in terms of business operations. Throughout its history, therefore, the IS discipline in Australia has had a strong focus on application software and technology in use, and seldom on hardware or even systems software. 
Because the bare machine had to be oriented to business needs, software development was an essential focus from the emergence of IS, through the 1970s and until the late 1980s. A long-running strand of the discipline has focused on development tools and methods (often referred to using the inappropriate term 'methodologies', even in the key reference work, Olle et al. 1988). The software development life cycle (SDLC) was important in the IS departments of universities and was central to the many computing and (E)DP departments in more vocationally oriented institutions. Considerable attention has also been paid to the productivity and quality aspects of software development, giving rise to specialised strands within the discipline that overlap with - and are seen by some to have migrated across to - software engineering.

Through the 1980s, the 'structured era' matured. A comprehensive set of methods and associated tools was accumulated, which ensured completeness across the three dimensions of system designs: procedures, data models and control structures.

Concern had arisen, however, about the slowness and resource intensiveness of development using the structured techniques. Theories emerged about 'rapid-application development' (RAD). This sacrifices quality in order to gain speed and cost savings in the development process, and hence some prefer the more descriptive title 'quick and dirty' (QAD). During the 1990s, RAD and 'object-oriented' techniques overran the structured techniques, and they remain the technological mainstream.

During the same period, there was a substantial de-skilling of designers and programmers as their roles were converted into commodities (as encapsulated by the expression 'everyone thinks they can design an e-commerce web site'). These changes have resulted in a reduction in the quality of software, with large numbers of fragile and poorly and even undocumented applications, continued project failures and overruns and-particularly since the explosion of Internet-based applications - seriously low security.

During the 1980s - and in parallel with the rise of the structured techniques - the SDLC gradually matured into a systems life cycle (SLC). This distinction reflected the importance of non-software elements. It also acknowledged the need for maintenance and enhancement, and not just of software, but of business processes that integrated the manual, automated and intellectual elements. The area has been revisited and rebadged from time to time, most successfully during the 'business process re-engineering' phase. 
Although programming and software engineering have eased away to the very edge of IS, and even systems design has become a boundary topic, systems analysis has remained within the IS discipline's scope. The approaches adopted within Australia have tended to moderate the hard-line, technology-driven approaches, which have emanated primarily from the United States, by adopting elements of the more tolerant and ambiguous notions of the UK school of thought. Therefore texts such as the Yourdon series during the 'structured' era, Booch and Rumbaugh during the later 'object-oriented phase' and Kendall and Kendall, have lined up with and against texts such as Avison and Fitzgerald. The extreme end of the mechanistic/reductionist approach, characterised by IEEE 'requirements engineering' and championed by software engineers and computer scientists, continues to have some hold in the IS discipline. At the other extremity, there has been some penetration by participative design notions.

In interview, Cyril Brookes perceived DBMS, data management and data modelling to have been among the key enablers of the separation of IS from computer science in the mid to late 1970s: '[T] here was only so far you could go with structured programming.' For some years, data schemata, data dictionaries and information resource dictionary systems (IRDS), coupled with more abstract entity-relationship modelling and enterprise data modelling, were central concerns. In recent years, however, these too have drifted toward the edge of IS, and information management has been more prominent, with its emphasis on semantics, meta-data, information retrieval and information architecture.

During the 1960s and 1970s, and well into the 1980s, the work of most IS practitioners was focused on support for business operations. This involved using data to represent relevant events that occurred in the organisation's world. A useful generic term for these kinds of applications was 'transaction data-processing systems' (TDPS). The first specialist newsletter, the Data Base for Advances in Information Systems (usually shortened to Database), was launched in 1969. It was, and continues to be, published under the auspices of the ACM Special Interest Group on Business Data Processing (SIGBDP), which changed its name to SIGMIS in 1991. It became a refereed journal in 1979 (Canning 1994). The term 'BDP' was little used in Australia, the more mainstream expressions being electronic data processing (EDP) in most of the private sector, and automatic data processing (ADP) in the public sector.

Progressively, the belief arose that the information needs of managers and executives could and should be served; this gave rise to the MIS movement. The term was associated with Gordon Davis and his colleagues at Minnesota, and much of the drive for it emerged from there. The concept reached Australia very quickly (Aiken 1971). This author has always considered that the key text that set the agenda was Davis (1974), entitled Management Information Systems: Conceptual Foundations, Structure, and Development. In its later form, Davis and 
Olson (1984), it was still listed as a student reference for later-year undergraduates as late as the mid-1990s. MIS Quarterly began during this phase - in 1977—run out of Minnesota and supported by OR/MS and business organisations.

A key distinction between MIS and TDPS was the extraction of information from data, in particular through aggregation and exception reporting. The original concept is a natural extension of management accounting, but Davis and others quickly developed it much further. As noted earlier, MIS is the common term in the United States for the IS discipline as a whole.

Specialist conferences emerged about that time, with ICIS beginning in 1980. All of these activities were - and continue to be - heavily US-dominated, although many non-Americans travelled to the event, particularly from Europe and Australia, and the conference has been more meaningfully international since about 1990, with five of the last 15 conferences held outside North America. Since 1983, there has been a Minnesota-run North American Directory of Faculty ('faculty' in the American sense of 'academic staff' rather than the British and Australian sense of a collegial organisational unit).

The decision support systems (DSS) movement then augmented MIS. An ACM SIGBDP Conference in January 1977 addressed the topic (see also Keen and Scott Morton 1978 and Sprague 1980; although Banker and Kauffman 2004 claim that it was emergent in the management science community since the mid-1950s). DSS can be differentiated from MIS in two main ways. First, data extracted from TDPS and MIS is used in conjunction with models of current and possible future business, incorporating ideas from OR/MS. Second, data are used that derived from outside the organisation (such as demographics and costs of transport and of capital) and 'out of thin air' (as models were applied to 'what-if' analysis).

Subsequent developments included executive information systems (EIS), business intelligence (BI) and knowledge management (KM). Each was a fad driven by management consultants - 'new bottles for old wine' - but each has brought focus to particular aspects of the whole, and has drawn insights into the IS discipline from other disciplines and research domains.

Figure 2.2 provides a diagrammatic representation of the relationships among these building blocks of the IS discipline. 


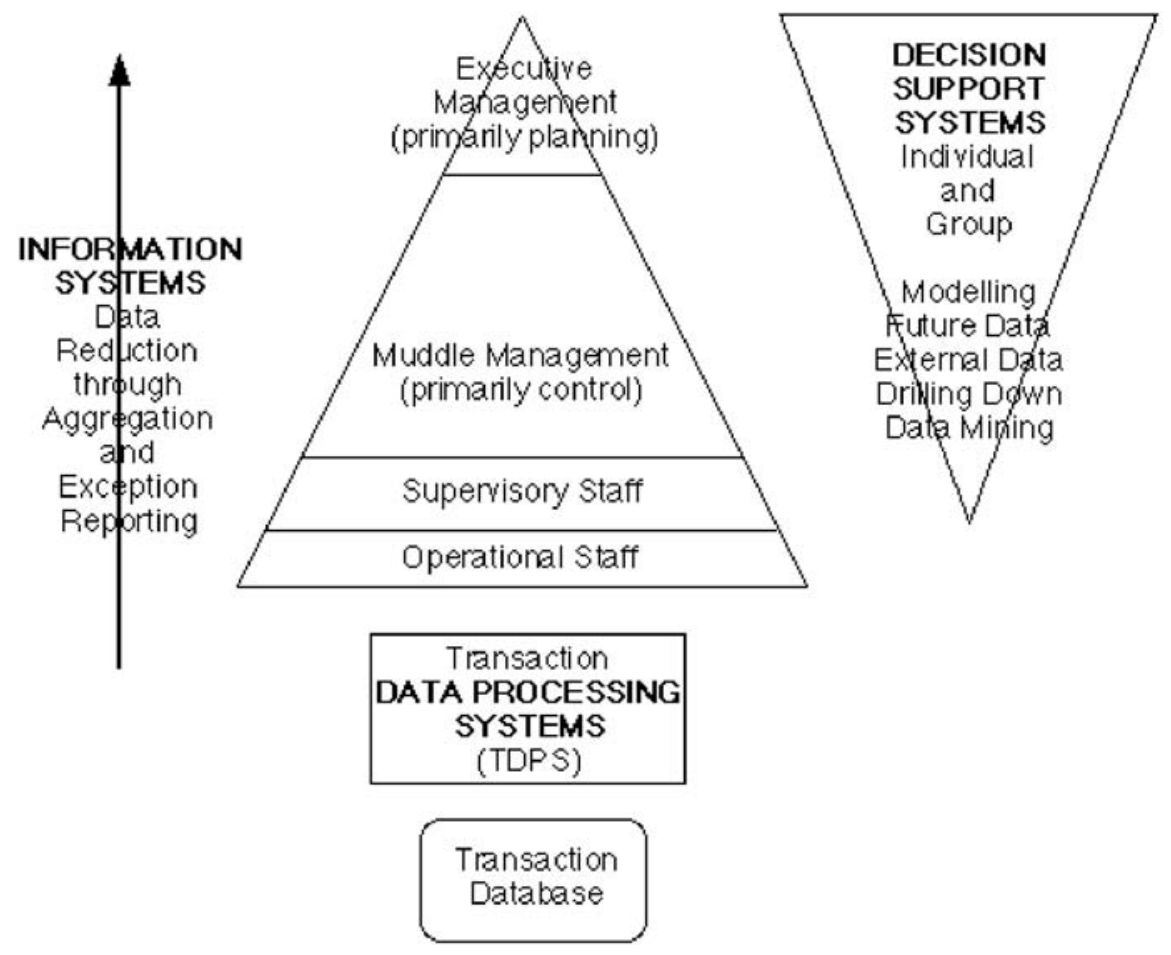

\section{Figure 2.2 Building blocks of the IS discipline}

Source: Clarke, R. 1990, 'Information systems: the scope of the domain', Xamax Consultancy Pty Ltd, viewed 22 March 2007, <http://www.anu.edu.au/people/Roger.Clarke/SOS/ISDefn.html>

A further strand reflected the inter-working of multiple individuals; this was group decision support systems (GDSS) and its correlation at the tactical level, computer-supported cooperative work (CSCW). This area is a good example of the way in which continuous technology-driven redefinition of scope has resulted in disciplinary splintering and scattered alliances. Other examples include human-computer interaction (HCI) and enterprise modelling. Such splintering has been a significant contributor to the inability of the IS discipline to build a substantial and stable power base.

Project management - although always a focus for the IS profession - has been performed poorly. This throws doubt on the quality of the teaching and research performed within the IS discipline. The need for formalised instruction in project management is higher now than ever before, because people in their twenties and younger have grown up with even less orientation towards planning than previous generations, because of their dependency on their mobile phone to perform just-in-time scheduling for everything that they do. 
As a consequence of increasing application complexity and low-quality project management, project failure and application failure have long been major concerns among executives. Mandata and the Bank of New South Wales' CS90 were very public examples of failure in the 1970s and 1980s. They have been a less significant focus of research work than might have been expected of a discipline closely attuned to business needs, although Chris Sauer's doctorate and book were important contributions. Much stronger focus has been needed on the balance between quality, whole-of-life cost and risk management on the one hand, and speed and development cost on the other. That focus has not, however, been forthcoming, and high levels of project failure and application failure therefore continue.

The application of IT to particular categories of data (for example, text, numerical data and geographical data), and in particular industry sectors (for example, logistics/supply chain, health, justice and air traffic control), has tended to be at the fringe of the IS discipline. The intersection with the discipline of accountancy through accounting information systems has been crucial to a significant minority of the discipline's members, but has been seen as largely irrelevant by many others.

Applications in the 1960s and early 1970s were conceived within limited functional areas (in accounting contexts, the 'sub-ledgers' such as debtors, creditors, inventory, payroll and general ledger). The 1970s saw more effective interfacing between what began as stand-alone applications. Through the 1980s, applications were progressively integrated into larger products (such as, initially, financial management information systems, FMIS, and, later, the poorly named enterprise resource planning products, ERP).

During this period, a major change that had implications for the discipline's focus was the transformation from custom-built to packaged applications. As software became more complex, and more expensive, the focus switched from development to the acquisition of packages, and the customisation and integration of pre-written components. As indicated earlier, this transition occurred in areas such as payroll during the early 1970s, and for larger and more complex applications as late as the early to mid-1990s.

Theorists appreciated from the outset that, as the number of elements and the size of the source code grew, there would be an exponential growth in difficulties (such as bug content, the incidence of new bugs arising from fixes of old bugs, fragility, comprehensibility, the investment required in application-specific staff training, inflexibility and non-adaptability). Large-scale products have not reflected these insights sufficiently well, and the tendency to move from modularity towards monolithism has resulted in enormously expensive, highly integrated software products. The quality of the many large-scale applications has become a progressively larger problem, the lead time for adaptation 
(frequently of the organisation and its business processes, rather than the software) has become very long and project risk continues to be very high.

Progressively, a wide array of IT-related services has come to be regarded as commodities as unrelated to organisations' core competencies as are cleaning services. What was once referred to as data-centre management-and now as server hosting - was an early candidate for outsourcing. User support-and more recently customer support through 'help centres' - has followed them, in some cases offshore. Inadequacies in service delivery and loss of managerial control have resulted in instances of subsequent re-sourcing. The concept of 'right-sourcing' resurfaces from time to time.

The management of computers, data processing, data centres and, progressively, IS, was a focus in some schools from the outset (through such leaders as Dickson at Minnesota and Anthony, Macfarlan and Scott Morton at Harvard). It expanded progressively into a broader IT management thread. By the late 1980s, the opportunities that communications technologies had created caused a great deal of attention to be paid to IS that crossed the boundaries of organisations - originally inter-organisational systems (IOS-1-to-1), then multi-organisational (MOS - m-to-n) in various configurations, particularly in the form of 'industry value chains'. The combination of DSS and IOS/MOS resulted in increased capacity to contribute to the work of the most senior executives in large organisations. From the late 1980s, the strategic information systems (SIS) strand became important, and 'strategic alignment' became a preoccupation.

Appreciation grew that enormous harm arises from mechanistic application of technology without sufficient attention to its use by people and organisations, and to its first-order impacts on, and second-order implications for, people and organisations. This was investigated by the socio-technical movement, associated with Mumford, Checkland, Wood-Harper and Bjørn-Anderson. The tension between the 'managerial paradigm' and the 'humanistic paradigm' is examined in Land (2000a). These have had much more substantial influence in Australia than in North America. A few specialist journals exist, such as Information Technology \& People and The Information Society, but they are somewhat marginalised.

The rationalist correlation of socio-technics and soft-systems techniques has been change management, which has loomed large in recent years for several reasons. One is the rapidity of technological advance. Another is the inevitable tendency of organisations to fall behind 'the technology curve', and then lurch into catch-up mode, with equally inevitable negative impacts on staff morale. A further factor is the entrenched distinction between management and operational staff, and the limited involvement of operational staff in the analysis of requirements and the design of new systems. Scandinavian 'participative 
design' and Japanese 'quality circles' and kaizen ('continuous improvement') have all made limited headway in breaking down simplistic top-down management notions.

By the late 1980s, the convergence of computing with communications was making rapid progress. Local-area networking (LAN) and later wide-area networking changed the scope of the industry that IS was bound up with from 'the computer industry' in the 1970s to 'the IT industry' in the 1990s. Subsequently, user satisfaction, technology use, technology adoption and impediments to adoption have been major focal points of IS research. The theory of reasoned action (TRA) and the technology-adoption model (TAM) are examples of theories drawn into IS from reference disciplines, and much applied - although with limited practical impact.

A range of economic perspectives and tools has been applied, resulting in sub-disciplines, or perhaps research domains, of the economics of IS and of IT. These focus on topics such as the productivity of developers, of user organisations and of industry sectors; the processes of technology diffusion; and the balance between hierarchies and markets.

Indications of the current structure of the body of knowledge are provided by the current ACS Accreditation Guidelines (Underwood 1997, under revision) and current curriculum guidelines, in particular, recent references such as Gorgone and Gray (2000), Gorgone et al. (2002, 2005).

From this necessarily brief outline, it is clear that the scope of the discipline has broadened over the years, and has been driven largely by technological change - and to a lesser extent by organisational needs. There has been only limited evidence of leadership by the IS discipline in technological innovation, although somewhat more evidence of contributions to the management of applications of technology.

\section{Political dimensions}

This section draws together some key aspects of the difficulties that the IS discipline in Australia has encountered, in relation to its international context, its organisational location within universities, its relationships with the IS profession and with industry more generally, its political weakness and the resultant resource constraints.

\section{International orientation and impact}

Australians have always been acutely aware of the need to be in contact with the discipline elsewhere in the world, and have been active travellers since the late 1970s, as conference contributors, participants and program committee members, as doctoral candidates, as seminar speakers and in short-term visiting positions. 
A small number of Australians have held positions overseas for extended periods, particularly in the United States, including Ted Stohr at New York University from the late 1970s, Iris Vessey at Pittsburgh, Penn State and Indiana from the late 1980s, Rick Watson at Georgia from the late 1980s, and more recently Peter Weill at Massachusetts Institute of Technology (MIT). (All were to a considerable extent Australian educated, and all except Vessey were born in Australia). The flow has been far from one way. Migrants and visitors have included Britons Philip Yetton (at the Australian Graduate School of Management from 1976, although active in IS only from 1993), Bob Galliers (1982-89 at the West Australian Institute of Technology/Curtin, and subsequently Dean of the Warwick Business School) and Janice Burn (1997-2005 at Edith Cowan University); Canadian Guy Gable (since 1995 at QUT); and American Michael Vitale (1995-2001 at Melbourne University and subsequently Dean of the Australian Graduate School of Management).

Australia has also attracted many visits from leading overseas IS academics. The 1984 and 1988 ACS/IFIP Conferences were an important stimulus. Some who have made multiple and/or lengthy visits include Frank Land (LSE, LBS), Bill Olle (London), Neils Bjørn-Andersen (Copenhagen), Leslie Willcocks (Warwick), Trevor Wood-Harper (Salford), Rudy Hirschheim (Houston), Doug Vogel (Arizona, later City University of Hong Kong), Felix Hampe (Koblenz) and Michael Schrefl and Gerald Quirchmaier (both of Linz).

Given that Australia represents about 0.3 per cent of the world's population and about 1 per cent of global gross domestic product (GDP), Australia tends to punch above its weight in many fields. For example, three of the 13 AIS presidents have been Australian born (Ron Weber, Richard Watson and Philip Ein-Dor). Although the impact of Australia's approximately 700 IS academics has been noticeable, it has, however, been dwarfed by the energy of the United States. Appendix 2.3 provides an analysis in support of that conclusion.

One reason for this doubtless is the slow emergence of doctoral programs in Australia. Until the 1990s, most candidates had to either manage their own preparation with support from one or more supervisors but little formal preparatory study or leverage as best they could off relevant (and often not so relevant) units of study in adjacent disciplines. Even at the end of that decade, however, Metcalfe and Kiley (2000) found it necessary to argue for $\mathrm{PhD}$ course-work. Frank Land provided an important perspective - which confirms the author's experience - that at least during the period to 1995, Australian PhDs in IS were generally expected to submit to examination by top-quality international figures. This might be explained by the high standards demanded of pioneers in an emergent discipline, or by the exquisitely Australian concept of 'cultural cringe' - or more likely by a combination of both. 
A range of institutions in Australia now offers more structured preparation for IS doctoral candidates. There might therefore be an expectation of some acceleration in Australians' contributions in the most heavily weighted journals and the ICIS. That development might be confounded, however, by the continuing high productivity of American scholars, the higher productivity of journal publication by European scholars in recent years, the explosion in doctoral programs in other countries and the prevalent attitude that there are only about five top-level journals (despite the explosion in IS and IS-relevant journals in the past 15 years - 565 currently, according to Lamp 2004 - and the high quality of far more than a mere five of them).

\section{Discipline size and staff location}

The organisational location of IS staff has been highly varied from the outset. A large proportion of IS academics has always been in departments dominated by other disciplines, for which IS was, and in many cases still is, perceived to fulfil a service role. The dominant disciplines have been variously welcoming and hostile to the IS discipline and the staff working in it.

Almost all institutions had specialist organisational units focused on IS by the end of the 1980s. The last two of the major institutions to create them were regarded widely as being among the most conservative: the University of Melbourne (1995) and the University of Sydney (2001).

The statistical data in Table 2.2 were extracted from the various editions of the printed Directories of Australian Academics (Clarke 1988), Australasian Academics (Clarke 1991) and Asia Pacific Researchers (Gable and Clarke 1994, 1996), and the online directory as of 2 May 2005 and 22 March 2007. The entries in the printed directories were managed, whereas those in the online directory have been, and remain, self-reported and unaudited. There is known to be a substantial 'staleness' factor, with many individuals not amending their entries when they move, and particularly when they leave the discipline altogether. There is also clear under-reporting - for example, only 30 of the 52 identifiable professors had entries in March 2007. The data have been analysed notwithstanding such issues, because to some extent the inaccuracies cancel one another out, but primarily because (in what might be regarded as a parable of the relevance-versus-rigour debate) that is all that is available to analyse. 
The Information Systems Academic Discipline in Australia

Table 2.2 Institution and staff statistics

\begin{tabular}{l|l|l|l|l|l|l}
\hline & IS depts & Departments & $\%$ & Institutions & Individuals & Professors \\
\hline 1988 & 9 & 55 & 16 & 41 & 175 & 2 \\
\hline 1991 & 22 & 76 & 29 & 39 & 521 & 7 \\
\hline 1994 & 32 & 84 & 38 & 38 & 640 & 13 \\
\hline 1996 & 39 & 88 & 44 & 39 & 630 & 15 \\
\hline 2005 & 28 & 103 & 28 & 42 & 670 & 30 \\
\hline 2007 & 24 & 85 & 28 & 41 & 396 & 30 \\
\hline
\end{tabular}

Note: The counts of individuals in 2005 and 2007 have been adjusted to remove PhD students and adjuncts, in order to sustain comparability with the earlier figures

Table 2.2 shows that, by 1988, when the first Directory of Information Systems Academics was produced, the 175 individuals who could be identified readily were in 55 separate departments in 41 educational institutions. Only nine of those 55 departments were recognisable as IS, with a further eight in computing or (electronic) data processing. In a pattern that has continued to the present day, 25 of the departments were dominated by business disciplines (six each of commerce, accounting and business; three each of management and economics; and one of administration); and computer science departments dominated the remainder, with some information science (in the technical rather than the librarianship sense) and mathematics. A significant difference from the patterns that are evident in the United States has been the relatively limited involvement of and interest in IS by Australian graduate schools of business, especially until about the mid-1990s.

The proportion of departments hosting IS staff that were named IS or similar grew steadily to nearly half, but plummeted after the end of the 1990s. This followed the 'dotcom implosion' about 2000 and the external financial pressures on universities, which have encouraged the imposition of departmental amalgamations in the hope that this will result in cost savings.

Analysis requires care. The count of individuals in 2005 included people who were no longer active in the IS discipline but whose entries had not been deleted. In early 2007, a purge of old records was undertaken, removing those that had not been updated since 2000 and where a message to the email address elicited no response, or a bounce message that indicated it no longer existed. This author (who was an editor of the directory from its establishment in 1988 until 1996) estimates that the 1996 figures over-counted by 10 per cent and under-counted by about the same amount, whereas, under the subsequent self-managed online scheme, over-reporting increased (until corrected in 2007) and the under-reporting increased as well (with no correction made as yet). Taking these factors into account, the contraction post-2000 would appear to have been 25-35 per cent. This is broadly consistent with anecdotal evidence and examination of a sample of institutions - although there was considerable variance among institutions in the timing and the scale of the contraction. 
The approximately 400 people in the directory in 2007 under-reports the total count. If the under-reporting for all levels of staff is the same as that by professors, a factor of 52/30 or 1.73 needs to be applied, suggesting that in 2007 there were close to 700 people for whom IS was their dominant disciplinary affiliation, scattered across at least 85 departments (of which only 28 were distinctly IS or similar in name), in almost all institutions. This is broadly consistent with the finding in Pervan and Shanks (2006) of 460 staff in 24 respondent institutions of an estimated 36 (after allowing for probable over-sampling of the larger institutions). On the basis of directory entries in March 2007, the largest concentrations of IS academics appear to be at (in descending order) Melbourne, Monash, QUT, the University of South Australia, Edith Cowan, Deakin, Griffith and UNSW.

Pearcey wrote nearly two decades ago (1988:125) that ' $[\mathrm{t}]$ he demand for people with computing expertise has always outstripped the capacity of the tertiary sector to supply it, and the situation seems unlikely to change'. Based on personal experience, that was the case for at least three decades, from the late 1960s until the end of the 1990s. About 2000, several factors conspired to dramatically reduce demand. The burst of the dotcom bubble about 2000 undermined the attractiveness of all IT-related courses. In addition, offshore outsourcing had been extending progressively from data capture to programming and even detailed design work. The commoditisation of many skills has also resulted in transfer from the university sector to the vocational education and training (VET) sector.

The publicity accompanying this large market correction was followed by substantial reductions in enrolments from domestic students - although it appears to have had a smaller impact on foreign fee-paying numbers. As is the way with 'the invisible hand' so beloved of economists, it appears likely that the slump will have been an over-correction, and that there will soon be shortages in graduates and in IS staff.

\section{Relationships with the IS profession}

Few members of the IS discipline would regard it as being intellectually remote and abstract. On the contrary, it is generally regarded as a professional discipline. One indicator of this is the fact that major contributions to the foundations of IS by Ron Weber and Canadian colleague Yair Wand (for example, Weber 1997) have been admired widely, but also ignored widely.

A professional discipline needs to be clear about who the professionals are whom the discipline needs to educate, interact with and conduct research for. The nature of the profession has, however, changed considerably over the years. It began with strong scientific credentials in the 1960s, but many of the people who surged into the field in the 1970s and even more so in the 1980s had no 
degree in a relevant discipline. The endeavours of the ACS to ensure appropriate preparation for careers in IS have been only partly successful, not least because of the rapid technology-driven changes in work patterns, business needs and IT management fashions.

Professional job titles and job definitions have changed a great deal in the four decades that the profession and discipline have existed. The original roles were computer operator (now largely defunct), systems analyst (now more commonly called business analyst), systems designer (often referred to as systems analyst/designer, and sometimes business process engineer, but diminished due to the contemporary dominance of packaged software) and programmer. The senior staff member was once called an electronic or automatic data-processing (EDP or ADP or just DP) manager. The executive to whom that manager reported was most commonly the finance director.

Chief technology officers (CTOs) and CIOs emerged at executive level only from the mid to late 1980s onwards, as the strategic significance of IT grew-and as the amount of money spent on it sky-rocketted. CIOs, who should be a natural connection point for senior IS academics into the world of business and government, commonly have no qualifications in IS, but rather are generalised executives thrust into a particularly challenging role.

Because graduates from IS courses are intended to move into the profession, the professional body, the ACS, has long run an accreditation program. Most institutions have felt the need to have their computing courses accredited by the ACS - as a form of review and as a means whereby graduates can be assured of qualifying for membership of the relevant professional body. For many years, the ACS's accreditation guidelines mentioned the term 'information systems', but were oriented heavily towards computing and were dominated by computer science thinking (ACS 1985, 1987). Through the 1980s, many IS courses achieved accreditation only through the exercise of the discretion that the guidelines permitted the assessors. A mature IS discipline and profession needed more than this.

In 1989, this author and Bruce Lo proposed that the accreditation requirements for IS be distinguished from those of computer science, and that they reflect technology and business needs (Clarke and Lo 1989). The proposal was adopted in ACS (1990), and retained in Maynard and Underwood (1996). Underwood (1997) provides a more detailed description of the 'core body of knowledge for IT professionals', and reflects the computer science and IS perspectives on the domain.

The tension between the technology driver and the organisational aspect was exemplified by the competition between the ACS and the Australian Institute of Systems Analysts (AISA) during the 1970s. In this case, the computing end of the spectrum won by a very wide margin. The AISA, despite its organisational 
orientation, never grew into an association with significant membership or influence. Nor did any of the larger business-oriented professional associations ever make a significant move to capture the business-analysis profession. Despite this, membership of the ACS has remained fairly steady in the past several decades (between 12000 and 16000 ), reflecting a reduction in the proportion of people active in the field who are members.

Influence by the IS discipline on the ACS has been muted. For example, the presidency has been held by people outside IS for only six of the society's 40 years. For 32 of the 40 years, the president has been a senior IS professional (Ashley Goldsworthy's five years preceding the period he spent in academia). For a total of only two years has a member of the IS discipline been president (Alan Underwood, in 1990-91).

\section{Relationships with industry}

The IS discipline needs linkages broader than the IS profession, reaching out to other business functions and to executive levels of business and government. One form of linkage has been course and departmental advisory committees, which facilitate input from industry to the discipline. Information systems departments have also tended to draw heavily on people within industry for sessional tutors, sessional lecturers, guest lecturers and sometimes for adjunct appointments. In interview, Gerry Maynard mentioned the use by Caulfield Institute of 'pleasant Friday afternoons', which were used as a means of drawing DP managers in industry and government into contact with staff and students. A primary motivation for employers was the attraction of good graduates, whereas educational institutions stood to gain funding support and intellectual interaction.

The Australian Computer Users Association (ACUA) operated from 1968 onwards. Although it was a potential linkage point for senior academics, it does not appear that it was much used in that manner. UNSW ran a very successful IS forum from 1977 onwards, which drew in senior executives from industry and government. This was much easier than for many other institutions because Cyril Brookes had moved into academia from what was arguably the top private-sector computing position in Australia: Manager, Corporate Data Processing, for what was then the country's largest company, BHP. Only a small number of IS departments appear to have been able to build and sustain linkages of this nature, primarily those in the more prestigious graduate schools of management.

The ACS/IFIP TC8 Conferences in Sydney in April 1984 and March 1988, organised by UNSW's Brookes and Ross Jeffery and the senior IS professional and ACS officer Ann Moffatt, had the express purpose of establishing a bridge between industry and academia. That team's success with industry linkage was 
reflected in the Institute of Information Technology, run at UNSW for IBM from 1987 to 1992.

During the 1980s, there was considerable emphasis among employers on 'sandwich courses', and flagship degrees were very successful at UNSW and UTS in Sydney, and at Monash and Swinburne in Melbourne. The perception in industry was that, particularly at the more applied end of computer science and the technical end of IS, quality graduates were being confronted by real-world problems too late. Sandwich courses provided students with early exposure to the work environment, enabled theory to be leavened with practice and created the possibility that practice could leverage off theory.

Course-work was originally entirely the responsibility of academics. There has been a drift in recent years towards outsourcing, as resource pressures in universities increase. A larger proportion of units of study appear to be being taught directly from textbooks, chapter by chapter, with less bespoke design to fit local needs. In addition, industry-provided product-specific units have come to be accepted for credit within some universities (for example, networking by Cisco and .NET development by Microsoft). The eternal relevance-versus-rigour tussle in research is mirrored by the training-versus-education battle in the learning context.

\section{Political weakness and resource constraints}

For an extended period, there was competition for dominance in the IS discipline between computer science on the one hand and business, commerce or accounting on the other. Dreyfus (2004) chronicles the establishment of the last IS department, at the University of Melbourne, which occurred during the period 1994-96. The Vice-Chancellor, David Penington, requested a report from a committee chaired by Peter Weill (who was an IT management professor in the Graduate School of Management). The Weill report stressed that there was no one standard structure for IS across the universities, with some courses management oriented, while others were highly technical. Penington opted to put the new IS department in the science faculty, at least for the short term, although housed close to computer science. The IS degree was to have five major themes: information systems, organisations, IT, analytical skills and personal competency. Later-year specialisation was to be in one of three streams: organisations, IT or custom (Dreyfus 2004:1-6). As it has transpired, the department quickly developed a sufficient scale and power base, and more than a decade later its faculty location remains unchanged.

A comparison between the experiences of the Australian IS and computer science disciplines is instructive. In 1990, the numbers of academic staff in IS and computer science were comparable; however, whereas computer science staff were concentrated in departments bearing that or a similar name, IS staff were 
distributed through many departments, in many cases without a senior academic post allocated to the IS discipline. The diffusion of IS staff has meant that for many years IS has lacked political clout, and even now has less political clout than other disciplines with similar total numbers. Computer science, for example, has demanded and attracted far greater funding and support staff, and it has always been far more influential and better recognised than IS.

One implication of the lack of political power has been a lack of resources for educational functions. In most institutions, there was a long-term struggle to gain sufficient funding and staff positions (and then to find people with appropriate education and experience to fill them). In some contexts, the computer science discipline was powerful and resisted the emergence of IS. In others, economics and management disciplines did the same. The joint majors and double degrees that the market needed emerged very slowly, and the silo effects of faculties, schools and even departments resulted in students often having to devise ways to construct programs that suited their interests, and their perceptions of current needs.

Another problem has been the serious difficulty of acquiring sufficient resources to support research programs, or even individual projects of significant scale. Members of the discipline in Australia were under-trained in research, they were highly diverse in their orientations, domains of study and research techniques, and they were scattered geographically. The development of consortia to develop quality bids was difficult, and remained so well into the era of widespread e-mail that began with the launch of AARNet in mid-1989 (Clarke 2004).

The primary source of funding, the Australian Research Grants Scheme (ARGS), later the Australian Research Council (ARC), created a sub-topic of IS only in the late 1990s. Until then, those few who were successful in their bids submitted under either computer science or management headings, and were generally assessed by academics with no affinity with the IS discipline.

Since 1998, IS has been recognised within the ARC RFCD Code as one of 139 disciplines and 898 subjects. The 17 most directly relevant subjects are listed in Table 2.3. The first 13 are in the discipline of IS, within the information, computing and communication sciences cluster, and the other four are applications within particular disciplinary areas, including business. It appears, however, that a revision of the RFCD Code could be placing these IS-specific classifications under threat.

In 2001, after lobbying by ACPHIS and the then new AAIS, the IS discipline gained a member of the ARC's College of Experts. Panel members from the IS community since then have been Janice Burn (Edith Cowan), 2001-03, Graeme Shanks (Monash), 2004-05, and Michael Rosemann (QUT), 2006-07. 
Table 2.3 ARC codes for IS, from 1998

\begin{tabular}{l|l|l}
\hline & Code & Description \\
\hline & 280101 & Information Systems Organisation \\
\hline & 280102 & Information Systems Management \\
\hline & 280103 & Information Storage, Retrieval and Management \\
\hline & 280104 & Computer-Human Interaction \\
\hline & 280105 & Interfaces and Presentation (excl. Computer-Human Interaction) \\
\hline & 280106 & Inter-Organisational Information Systems \\
\hline & 280107 & Global Information Systems \\
\hline & 280108 & Database Management \\
\hline & 280109 & Decision Support and Group Support Systems \\
\hline & 280110 & Systems Theory \\
\hline & 280111 & Conceptual Modelling \\
\hline & 280112 & Information Systems Development Methodologies \\
\hline & 280199 & Information Systems not elsewhere classified \\
\hline & 321203 & Spatial Information Systems \\
\hline & 350202 & Health Information Systems \\
\hline & 390301 & Business Information Systems (incl. Data Processing) \\
\hline
\end{tabular}

\section{Intellectual dimensions}

The IS discipline in Australia faces serious challenges, and this chapter needs to offer a greater contribution than merely a historical recitation and analysis. This section addresses the important questions about the future: 'What do we regard as appropriate domains in which to conduct research?' and 'What research techniques are appropriate?'. It also lays the foundation for a further question discussed in Chapter 12: 'What unresolved tensions remain at the end of the discipline's fourth decade?'.

\section{The research domain}

An earlier section considered the drivers and scope of the IS discipline primarily from the teaching perspective. This sub-section considers the related, but somewhat different, question of what IS academics have considered appropriate areas of research.

Early endeavours to define the scope included Mason and Mitroff's (1973) program for research on MIS, Ives et al.'s (1980) framework for research in computer-based MIS, Galliers' manifesto for Australian-based research (1987) and Jeffery and Lawrence's special issue on current research directions in IS (1986). Reviews of the research undertaken in IS include Culnan (1986, 1987), Alavi et al. (1989), Alavi and Carlson (1992), Glass (1992), Avgerou et al. (1999), Galliers and Whitley (2002), Vessey et al. (2002) and Banker and Kauffman (2004). Each of these draws attention to the enormous breadth of the topics addressed. The diversity arises in at least two dimensions: 
- cross-sectionally, reflecting:

the diversity of origins

the diversity of host disciplines and co-located disciplines

- longitudinally, as drift occurs over time, driven by changes in technology, in fashion, in management and in management disciplines, and increasingly in fashion within the IS discipline itself.

A few attempts have been made to adopt the encyclopaedists' approach of enumerating the topics that are within the scope of the IS discipline. More adventurously, a few have attempted taxonomies, in order to impose some order on the chaos. The most successful work of this kind is that by Barki et al. (1988, 1993). The second paper reported that articles published in just seven major journals in 1987-92 identified about 2000 different keywords. Barki et al.'s revised classification scheme of 1993 included 1300 keywords under nine major and 56 minor groupings - an increase of 175 on their original 1988 version. It appears that the Herculean task has not been repeated since. Moreover, the use of the Barki scheme appears to have subsided, as reliance on brute-force, free-text search engines has increased. Nonetheless, it is a highly valuable tool of historical analysis.

As Table 2.4 shows, about only half of the Barki et al. (1993) keywords were concerned directly with the core areas of the IS discipline; one-quarter were associated with reference disciplines, and one-quarter with external drivers and constraints. The discipline could be described, kindly, as being strongly professional in its orientation and sensitive to its environment and the needs of its clientele. Alternatively, it could be depicted more critically, as lacking confidence, being derivative, lacking in fundamentals and driven mercilessly by its rapidly changing context.

Table 2.4 Barki et al.'s 1993 keyword list for IS

\begin{tabular}{l|l|l}
\hline Category & & $\%$ \\
\hline Reference disciplines & & $\mathbf{2 5}$ \\
\hline Drivers and constraints & & $\mathbf{2 5}$ \\
\hline Information technology & 12 & \\
\hline Organisational environment & 6 & \\
\hline External environment & 7 & \\
\hline IS core research areas & & $\mathbf{4 7}$ \\
\hline IS management & 16 & \\
\hline IS development and operations & 14 & \\
\hline IS usage & 5 & \\
\hline Kinds of information systems & 11 & \\
\hline IS education, research, etc. & & $\mathbf{3}$ \\
\hline
\end{tabular}

A later analysis examined articles published in Information \& Management and MIS Quarterly from 1981 to 1997, using the Barki high-level structure. Claver et al. (2000) found that the largest concentrations of publications were IS 
development (13.2 per cent of 1121 papers), DSS (8.9 per cent) and IS evaluation (7.8 per cent). Avgerou et al. (1999) evaluate research foci and methods in Europe, and Galliers and Whitley (2002) analyse the papers accepted at ECIS conferences.

Studies of this nature conducted in Australia include Galliers (1987), Ridley et al. (1998), Pervan and Cecez-Kecmanovic (2001) and Pervan and Shanks (2004, 2006). Pervan and Cecez-Kecmanovic (2001) reported on the results of a survey of heads of IS groups regarding the research profiles of their groups. The heads of 21 of the 36 targeted IS groups responded. This represented more than 400 of the approximately 700 IS academics thought to be active in IS in Australia. The responses confirmed that Australian IS reflects the enormous breadth of scope elsewhere. Similar diversity was detected in relation to the unit of analysis of the research conducted. The primary beneficiaries of the research were identified as being predominantly IS professionals and managers - consistent with the notion of being a professionally oriented discipline-although the subsequent data in Pervan and Shanks $(2004,2006)$ suggest a strong focus on writing for other academics as well. The average publication count disclosed was about two for each staff member per annum, of which one-third was in journals and two-thirds in conferences. The research funding available was generally small, but Pervan and Shanks (2004) suggested that it was growing.

\section{Research techniques}

The diversity apparent in research topics is just as evident in IS academics' choice of research methods. Taxonomies of research techniques include Alavi and Carlson (1992) and Palvia et al. (2003, 2004). The 1980s saw an extended period of intolerance and mutual distrust and dislike between groups who adopted particular research techniques. The tensions were variously methodological, philosophical and transatlantic. While differences remain, there is sufficient mutual respect and 'agreement to disagree' that little energy has been wasted during the past decade. The discipline has become catholic, in one of the positive senses of the expression.

In the IS community internationally, Claver et al. (2000) found that 'theoretical studies' (as defined by Alavi and Carlson 1992) fell from 56 per cent to 20 per cent between 1981 and 1983 and 1996 and 1997, while empirical studies rose from 44 per cent to 80 per cent. 'Field studies' (although in many cases mere questionnaire-based surveys) rose from 18 per cent to 52 per cent, while case studies rose to a high of 23 per cent but fell back to their original 18 per cent.

In Europe, Avgerou et al. (1999) found that the techniques used varied widely between countries, and differed from those prevalent in the United States. A large proportion of German researchers focused on technology development and testing, whereas those in many other countries conducted a great deal more qualitative analysis. 
In Australia, Pervan and Cecez-Kecmanovic (2001) reported that 'responses revealed dominance of a positivist paradigm, but the interpretivist paradigm was also often used'. Further, 'the full range of research methods are being used, from survey to action research, to technology development and testing'. Pervan and Shanks (2004, 2006) suggest that interpretivist approaches have been growing in popularity. Critical-theory approaches remain little used.

\section{Conclusions}

The purpose of this chapter has been to provide a chronicle of the early years of the IS discipline in Australia, in the process identifying important themes. It is arguably inappropriate in a review of this nature to draw conclusions; this section accordingly focuses on key questions that confront the discipline early in the twenty-first century.

The first cluster of questions relates to the discipline's intellectual survival. Is IS really a discipline? And does it matter if it isn't? Is there a core? Is it so heavily dependent on technology and management fashion that it can never have the stable core necessary for a recognised discipline? Put another way, are IS academics destined to wander forever, as Rosencrantz and Guildenstern to Hamlet, backstage bit actors to host discipline leads? Is IS not a discipline, but merely a research domain that needs to be viewed through the lenses of a variety of genuine disciplines? Has its value been ephemeral? Does it need to be absorbed by broader disciplines on either side of it? Does it need to continue to exist much as it does now, but with less energy wasted on existential angst?

In this author's view, we need to be far less nervous, and far more positive about the quality of our work; to be far less internally focused, and far more outward-looking and professionally oriented; to be far less interested in 'the IT artefact', and far more committed to 'information' and 'systems' as the once and future core of the IS discipline. We need to be far less mechanistic in our outlook, and far more humanistic; and we need to be far less servile to corporations and the State, and far more socially responsible.

If IS is a discipline with a long-term future, further questions arise. In interview, Frank Land said, 'We're fragmenting intellectually and methodologically, and our language is becoming confused, because words are increasingly being used in method-specific senses.' He sees this as leading to mistaken inferring and perhaps an outright inability to comprehend what someone from a different intellectual or methodological school of thought is trying to say. This author sees this as being a consequence of the dominance of rigour over relevance, and the resultant research technique-driven selection of research questions and even research domains.

If the discipline is intellectually worthy and sound, there remains the issue of economic survival. Can a still relatively young and politically weak discipline 
survive in the face of massively reduced government funding for institutions, new business models exposed to the vagaries of market conditions and a new mechanism for the distribution of research funds that is hostile to new and non-traditional disciplines? The market overreacted to the dot.com implosion-as markets do-and local demand for IT-qualified graduates could well exceed supply in the near future. The implosion in enrolments, however, confirmed the belief among university administrators that IS is ephemeral and/or unimportant. Will the recovery come soon enough and forcefully enough to ensure that IS survives as a distinct discipline? Political survival depends on many factors, but adjustment of the scope of the IS discipline, and maturation of its orientation, would deliver intellectual integrity, which would certainly help.

The first four decades of the IS discipline in Australia saw progress and growth achieved, but in a context of multi-dimensional change, uncertainty and adversity. The next decade promises more of the last three, but quite possibly more of the first two as well.

\section{Select bibliography}

Ackoff, R. L. 1967, 'Management misinformation systems', Management Science, vol. 14, no. 4, pp. 147-56.

Aiken, J. D. 1971, 'An introduction to management information systems', Australian Computer Journal, vol. 3, no. 3, pp. 98-105.

Alavi, M., Carlson, P. and Brooke, G. 1989, 'The ecology of MIS research: a twenty year status review', Proceedings of the International Conference on Information Systems, pp. 363-75.

Alavi, M. and Carlson, P. 1992, 'A review of MIS research and disciplinary development', Journal of Management Information Systems, vol. 8, no. 4, pp. 45-62.

Anthony, R. N. 1965, Planning and Control Systems: A Framework for Analysis, Harvard University Press.

Australian Bureau of Statistics (ABS) 2005, Informing a Nation: The Evolution of the Australian Bureau of Statistics, Australian Bureau of Statistics, cat. 1382.0, November 2005.

Australian Computer Society (ACS) 1985 Guidelines for Course Accreditation, Australian Computer Society.

Australian Computer Society (ACS) 1987 Guidelines for Course Accreditation, Australian Computer Society.

Australian Computer Society (ACS) 1990, Guidelines for Course Accreditation, Australian Computer Society. 
Australian Computer Society (ACS) 1992, Report of the Task Force on the ACS Towards 2000, Australian Computer Society, Sydney.

Australian Vice-Chancellors' Association (AVCC) 2004, Australian Higher Education Institutions, Australian Vice-Chancellors' Association, viewed 22 March 2007, <http://www.avcc.edu.au/documents/universities/ AustralianHEMerges-Amalgamations.pdf $>$

Avgerou, C., Siemer, J. and Bjørn-Andersen, N. 1999, 'The academic field of information systems in Europe', European Journal of Information Systems, vol. 8, no. 2, pp. 136-53.

Banker, R. J. and Kauffman, R. J. 2004, 'The evolution of research on information systems: a fiftieth-year survey of the literature in management science', Management Science, vol. 50, no. 3, pp. 281-98.

Barki, H., Rivard, S. and Talbot, J. 1988, 'An information systems keyword classification scheme', MIS Quarterly, vol. 12, no. 2, pp. 299-322.

Barki, H., Rivard, S. and Talbot, J. 1993, 'A keyword classification scheme for IS research literature: an update', MIS Quarterly, vol. 17, no. 2, pp. 209-26.

Bennet, J. M. 1963, 'EDP - the universities' role', Proceedings of the Australian Computer Conference, Group A-Commercial Data Processing, A. 16, pp. $1-16$.

Bennett, J. M., Broomham, R., Murton, P. M., Pearcey, T. and Rutledge, R. W. (eds) 1994, Computing in Australia: The Development of a Profession, Hale \& Iremonger/Australian Computer Society.

Bjørn-Anderson, N. (ed.) 1980, The Human Side of Information Processing, North-Holland, Amsterdam.

Bjørn-Anderson, N. and Hansen, H. 1993, European Information Systems Directory, Copenhagen Business School.

Boland, R. 1978, 'The process and product of system design', Management Science, vol. 28, no. 9, pp. 887-98.

Brookes, C. H. P., Grouse, P. J., Jeffery, D. R. and Lawrence, M. J. 1982, Information Systems Design, Prentice Hall, Sydney.

Burrows, G. 2006, Promise Fulfilled: The History of the Accounting Department at the University of Melbourne, Melbourne University Press.

Caminer, D., Aris, J., Hermon, P. and Land, F. 1998, LEO-The Incredible Story of the World's First Business Computer, McGraw-Hill, New York.

Campbell-Kelly, M. 2003, From Airline Reservations to Sonic the Hedgehog: A History of the Software Industry, MIT Press. 
Canning, R. C. 1994, 'History of the DATA BASE Journal', Database, viewed 22 March 2007, <http://www.baylor.edu/databaseJrnl/index.php?id=4298>

Checkland, P. 1981, Systems Thinking, Systems Practice, Wiley, Chichester.

Chen, W. S. and Hirschheim, R. 2004, 'A paradigmatic and methodological examination of information systems research from 1991 to 2001', Information Systems Journal, vol. 14, no. 3, pp. 197-235.

Clarke, R. (ed.) 1988, Australian Information Systems Academics: 1988/89 Directory, The Australian National University, November 1988.

Clarke, R. (ed.) 1991, Australasian Information Systems Academics: 1991 Directory, The Australian National University, April 1991.

Clarke, R. 1976, 'Top-down structured programming in COBOL', Proceedings of the 7th Australian Computer Conference, Perth, September 1976.

Clarke, R. 1987, 'The computing professional's bookshelf', Australian Computer Journal, vol. 19, no. 4, pp. 222-3.

Clarke, R. 1990, 'Information systems: the scope of the domain', Xamax Consultancy Pty Ltd, viewed 22 March 2007, $<$ http://www.anu.edu.au/people/Roger.Clarke/SOS/ISDefn.html>

Clarke, R. 1992, Fundamentals of 'Information Systems', Xamax Consultancy Pty Ltd, viewed 22 March 2007, <http://www.anu.edu.au/people/Roger.Clarke/SOS/ISFundas.html>

Clarke, R. 2004, 'Origins and nature of the Internet in Australia', Xamax Consultancy Pty Ltd, viewed 22 March 2007, $<$ http://www.anu.edu.au/people/Roger.Clarke/II/OzI04.html>

Clarke, R. 2006, 'Key aspects of the history of the information systems discipline in Australia', Australasian Journal of Information Systems, vol. 14, no. 1, pp. 123-40.

Clarke R. 2007, A Retrospective on the Information Systems Discipline in Australia-Appendices, Xamax Consultancy Pty Ltd, viewed 22 March 2007,

<http://www.anu.edu.au/people/Roger.Clarke/SOS/AISHistApps.html>

Clarke, R. and Lo, B. 1989, Accreditation Requirements for Information Systems Courses for the Australian Computer Society, Australian Computer Society, November 1989.

Claver, E., Gonzalez, R. and Llopis, J. 2000, 'An analysis of research in information systems (1981-1997)', Information \& Management, vol. 37, no. 4, pp. 181-95. 
Culnan, M. 1986, 'The intellectual development of management information systems, 1972-1982: a co-citation analysis', Management Science, vol. 32, no. 2, pp. 156-72.

Culnan, M. 1987, 'Mapping the intellectual structure of MIS, 1980-1985: a co-citation analysis', MIS Quarterly, vol. 11, no. 3, pp. 341-53.

Davis, G. B. 1965, Introduction to Electronic Computers, McGraw-Hill.

Davis, G. B. 1974, Management Information Systems: Conceptual Foundations, Structure, and Development, McGraw-Hill.

Davis, G. B. and DeGross, J. 1983, Information Systems Faculty Directory for North America, University of Minnesota.

Davis, G. B. and Olson, M. H. 1984, Management Information Systems: Conceptual Foundations, Structure, and Development, 2nd edn, McGraw-Hill.

Dearden, J. 1972, 'MIS is a mirage', Harvard Business Review, January-February, pp. $90-9$.

Dickson, G. W. 1981, 'Management information systems: evolution and status', in M. Youts (ed.), Advances in Computers, Academic Press, New York.

Dreyfus, S. 2004, The University of Melbourne Department of Information Systems - 1996-2004, University of Melbourne.

Drucker, P. F. 1968, The Age of Discontinuity, Pan Piper.

Emery, J. C. 1969, Organizational Planning and Control Systems: Theory and Technology, Crowell Collier and Macmillan, New York.

Emery, J. C. 1971, Cost-Benefit Analysis of Information Systems, The Society for Management Information Systems, Chicago.

Fiedler, M. R. G. 1969, 'Education for commercial ADP staff-I skills required and existing facilities', Australian Computer Journal, vol. 1, no. 5, pp. 277-84.

Fiedler, M. R. G. 1970, 'Education for commercial ADP staff in Australia II the solution in-house training', Australian Computer Journal, vol. 2, no. 1, pp. 32-8.

Gable, G. and Clarke, R. (eds) 1994, Asia Pacific Directory of Information Systems Researchers: 1994, National University of Singapore.

Gable, G. and Clarke, R. (eds) 1996, Asia Pacific Directory of Information Systems Researchers: 1996, National University of Singapore.

Galliers, R. D. 1987, 'Information systems planning: a manifesto for Australian-based research', Australian Computer Journal, vol. 19, no. 2, pp. 49-55. 
Galliers, R. D. and Whitley, E. A. 2002, 'An anatomy of European information systems research ECIS 1993-ECIS 2002: some initial findings', Proceedings of the 10th European Conference on Information Systems, Gdansk, Poland, June 2002.

Glass, R. L. 1992, 'A comparative analysis of the topic areas of computer science, software engineering and information systems', Journal of Systems and Software, vol. 19, no. 4 (1992), pp. 277-89.

Gorgone, J. T. and Gray, P. 2000, 'MSIS 2000: model curriculum and guidelines for graduate degree programs in information systems', Communications of the Association for Information Systems, vol. 3, no. 1.

Gorgone, J. T., Davis, G. B., Valacich, J. S., Topi, H., Feinstein, D. L. and Longenecker, H. E. jr 2002, IS 2002: Model Curriculum and Guidelines for Undergraduate Degree Programs in Information Systems, Association for Information Systems.

Gorgone, J. T., Gray, P., Stohr, E. A., Valacich, J. S. and Wigand, R. T. 2005, 'MSIS2006 curriculum preview', Communications of the Association for Information Systems, vol. 15, pp. 544-54.

Greig, J. and Levin, P. 1989, Computing at Chisholm: The First Twenty-Five Years, 1965-1989, Chisholm Institute of Technology.

Hally, M. 2005, Electronic Brains: Stories from the Dawn of the Computer Age, Granta, London.

Heinrich, L. J. 1993, Wirtschaftsinformatik-Einführung und Grundlegung, Oldenbourg, Muenchen/Wien.

Hudson, H. R. 1992, Report of the Discipline Review of Computing Studies and Information Sciences Education, Australian Government Publishing Service.

Ives, B., Hamilton, S. and Davis, G. B. 1980, 'A framework for research in computer-based management information-systems', Management Science, vol. 26, no. 9, pp. 910-34.

Jeffery, D. R. and Lawrence, M. J. (eds) 1986, 'Current research directions in information systems', Australian Computer Journal, vol. 18, no. 4, pp. $157-8$.

Johnson, L. R. 2006, 'Coming to grips with Univac', IEEE Annals of the History of Computing, vol. 28, no. 2, pp. 32-42.

Katz, D. and Kahn, R. L. 1966, The Social Psychology of Organizations, Wiley.

Keen, P. G. W. and Scott Morton M. S. 1978, Decision Support Systems: An Organizational Perspective, Addison-Wesley, Reading, Mass. 
Kistermann, F. W. 1991, 'The invention and development of the Hollerith punched card: in commemoration of the 130th anniversary of the birth of Herman Hollerith and for the 100th anniversary of large scale data processing', IEEE Annals of the History of Computing, vol. 13, no. 3, pp. 245-59.

Lamp, J. W. 2004, The Index of Information Systems Journals, Deakin University, Geelong, viewed 22 March 2007, $<$ http://lamp.infosys.deakin.edu.au/journals/index.php>

Land, F. 1992, 'The information systems domain', in R. Galliers (ed.), Information Systems Research: Issues, Methods, and Practical Guidelines, Blackwell, pp. 6-13.

Land, F. 2000a, 'Evaluation in a socio-technical context', in R. Baskerville, J. Stage and J. DeGross (eds), Organizational and Social Perspectives on IT, Kluwer, pp. 115-26.

Land, F. 2000b, 'The first business computer: a case study in user-driven innovation', IEEE Annals of the History of Computing, vol. 22, no. 3, pp. $16-26$.

Langefors, B. 1963, 'Some approaches to the theory of information systems', BIT Numerical Mathematics, vol. 3, no. 4, pp. 229-54.

Langefors, B. 1966, Theoretical Analysis of Information Systems, Studentlitteratur, Lund, Sweden.

Lee, A. S. 1994, 'Electronic mail as a medium for rich communication: an empirical investigation using hermeneutic interpretation', MIS Quarterly, vol. 18, no. 2, pp. 143-57.

Lyttinen, K. and King, J. L. 2004, 'Nothing at the center?: academic legitimacy in the information systems field', Journal of the Association for Information Systems, vol. 5, no. 6, pp. 220-46.

McDowell, I. 2002, 'Computing history-the first ANCCAC Conference', PC Update, March 2002, Melbourne PC User Group, Australia, viewed 22 March 2007, <http://www.melbpc.org.au/pcupdate/2203/2203article10.htm>

McGregor, K. 1974, 'University claims a computer first', Australian Financial Review, 29 January.

Mason, R. O. 2005, Putting 'Systems' Back into Information Systems: An Essay in Honor of Gordon Davis, Working Paper, May 2005.

Mason, R. O. and Mitroff I. I. 1973, 'A program for research on management information systems', Management Science, vol. 19, no. 5, pp. 475-87. 
Maynard, G. B. and Underwood, A. 1996, Guidelines for Accreditation of Courses in Universities at the Professional Level, Australian Computer Society.

Mertens, P., König, W. and Barbian, D. 2002, 'The German information systems perspective', Systémes d Information et Management, vol. 7, pp. 39-47.

Metcalfe, M. and Kiley, M. 2000, 'Arguing for PhD coursework', Australasian Journal of Information Systems, vol. 7, no. 2, pp. 52-9.

Mumford, E. 1983, Designing Human Systems, Manchester Business School.

Mumford, E. 2006, Socio-Technical Design, viewed 22 March 2007, $<$ http://www.enid.u-net.com/Sociotech.htm>

Mumford, E. and Banks, O. 1967, The Computer and the Clerk, Routledge Kegan Paul.

Norberg, A. L. 2005, Computers and Commerce: A Study of Technology and Management at Eckert-Mauchly Computer Company, Engineering Research Associates, and Remington Rand, 1946-1957, MIT Press.

Olle, T. W., Hagelstein, J., Macdonald, I. G., Rolland, C., Sol, H. G., van Assche, F. J. M. and Verrijn-Stuart, A. A. 1988, Information Systems Methodologies: A Framework for Understanding, Addison-Wesley.

Palvia, P., Leary, D., Mao, E., Midha, V., Pinjani, P. and Salam, A. F. 2004, 'Research methodologies in MIS: an update', Communications of the Association for Information Systems, vol. 14, no. 24.

Palvia, P., Mao, E., Salam, A. F. and Soliman, K. S. 2003, 'Management information systems research: what's there in a methodology?', Communications of the Association for Information Systems, vol. 11, no. 16.

Pearcey, T. 1988, A History of Australian Computing, Chisholm Institute of Technology.

Pervan, G. and Cecez-Kecmanovic, D. 2001, 'The status of information systems research in Australia: preliminary results', Proceedings of the 12th Australasian Conference on Information Systems, December 2001.

Pervan, G. and Shanks, G. 2004, IS Research Activity in Australia: Results of the 2004 ACPHIS Research Survey, Presentation to Australasian Conference on Information Systems, December 2004.

Pervan, G. and Shanks, G. 2006, 'The 2005 survey of information systems research in Australia', Australian Journal of Information Systems, vol. 14, no. 1, pp. 273-9.

Prince, T. R. 1966, Information Systems for Management Planning and Control, Richard D. Irwin, Homewood. 
Prince, T. R. 1970, Information Systems for Management Planning and Control, Richard D. Irwin, Homewood.

Ridley, G., Goulding, P., Lowry, G. and Pervan, G. P. 1998, 'The Australian information systems research community: an analysis of mainstream publication outlets', Australasian Journal of Information Systems, vol. 5, no. 2, pp. 69-80.

Sale, A. 1994, 'Computer science teaching in Australia', in J. M. Bennett et al. (eds), Computing in Australia: The Development of a Profession, Hale \& Iremonger/Australian Computer Society, pp. 151-4.

Scott Morton, M. S. 1971, Management Decision Systems, Harvard University Press.

Shen, Z. 2003, Langefors_Review, Wiki for IS Scholarship, viewed 22 March 2007, $<$ http://isworld.student.cwru.edu/tiki/tiki-index.php?page=Langefors_Review>

Simon, H. A. 1960, The New Science of Management, Harper, New York.

Smith, B. A. and de Ferranti, B. Z. 1975 Computer education needs in Australiathe next ten years, Commission on Advanced Education, Canberra, 6 vols.

Sprague, R. H. jr 1980, 'A framework for the development of decision support systems', MIS Quarterly, vol. 4, no. 4, pp. 1-26.

Underwood, A. 1997, The Core Body of Knowledge for Information Technology Professionals, Australian Computer Society.

Vessey, I., Ramesh, V. and Glass, R. L. 2002, 'Research in information systems: an empirical study of diversity in the discipline and its journals', Journal of Management Information Systems, vol. 19, no. 2, pp. 129-74.

Walstrom, K. A. and Leonard, L. 2000, 'Citation classics from the information systems literature', Information \& Management, vol. 38, no. 2, pp. 59-72.

Weber, R. 1997, Ontological Foundations of Information Systems: Coopers \& Lybrand Research Methodology Monograph No. 4, Coopers \& Lybrand, Melbourne.

White, J. D. and Palfreyman, E. H. 1963, 'Electronic data processing in the Commonwealth Public Service staff training', Proceedings of the Australian Computer Conference, Group A-Commercial Data Processing, A. 10, pp. 1-12.

Wood-Harper, A. T., Antill, L. and Avison, D. E. 1985, Information Systems Definition: The Multiview Approach, Blackwell, Oxford. 


\section{Appendix 2.1: Professors}

This appendix identifies individuals who are known to have occupied full professorial posts in Australia and whose background and role appeared to place considerable weight on IS. It was compiled during 2005-06 and revised in early 2007 with further edits in late 2007. It reflects the period up to early 2007. The confidence level is moderate - at an individual and an aggregate level.

In summary:

- in early 2007, the current count appeared to be 52 professors in 28 of the 42 widely recognised universities in Australia, although five of the 52 could be argued not to be professors in IS

- 70 individuals were identified as having held chairs, in 32 of the 42 institutions, although six could be argued not to be professors in IS

- the first 18 chairs appear to have been created between 1974 and 1995, as follows: 1974 (UNSW); 1981 (University of Queensland); 1987 (Curtin); five in 1990 (three at Monash, one each at UNSW, University of Queensland); 1991 (UNSW); 1992 (Tasmania); four in 1993 (Australian Graduate School of Management, Griffith, Macquarie Graduate School of Management, QUT); two in 1994 (Bond, Wollongong); two in 1995 (Macquarie, Charles Sturt University).

The three sections of this appendix are:

- an explanation of the basis on which the information was compiled

- a list of institutions, showing people known to have held full professorships there

- a list of people known to have held full professorships in IS, by surname, with such information as is known about their appointment(s).

\section{The basis of the compilation}

The starting points for this collection were the Australian and Asia-Pacific directories (Clarke 1988, 1991; Gable and Clarke 1994, 1996). It is of the nature of the early, printed directories and the self-maintained ISWorld Online Directory since 1995 that omissions and misclassifications occur. The proportion of IS professors who have established and maintained their own entries is very low (only 33 of 70). A '(D)' indicates that the person had an entry in the directory in March 2007 and '(NO)' means there was no entry.

The universities include all 38 that are members of Universities Australia (until 2007 known as the AVCC), together with four further institutions generally accepted as being universities.

Appointments in cognate disciplines such as accounting and computer science have been included, where the author judged the association with the IS 
community to be significant. One person listed has indicated that he no longer feels a close affinity with the IS discipline (Jeffery in empirical software engineering). At least five people would be regarded by some as being adjacent to rather than within IS (Gaffikin in accountancy, Henderson-Sellers in software engineering, Newton in computer science/OR, Orlowska in database and data management, Yetton in management and decision making).

The list does not include any of the following: associate professors, visiting professors, adjunct professors and professorial fellows (unless they were known to be full time for an extended period). The intention is to identify long-term, full-time positions and the people who occupy or have occupied them.

The years shown are only those during which the person is known to have held a chair - it is a list of professors, not an attempt to show each person's full career. This appendix includes the corrections and updates that were communicated to the author in response to a request for comment distributed to a large number of people in early 2007.

\section{List by institution}

Underlining indicates that the appointment was current in early 2007.

- Australian Catholic University (-)

- $\quad$ Adelaide (-)

- Australian Defence Force Academy (ADFA) - 2001 - Newton (1)

- Australian Graduate School of Management (AGSM)-1993, 2001-Yetton, Vitale (1)

- ANU-2001- Gregor (1)

- Ballarat (-)

- Bond-1994, 2003-Goldsworthy, Morrison, Finnie (2)

- Canberra (-)

- Charles Darwin University (CDU) - 2004-Lueg, Haynes (1)

- Charles Sturt University (CSU) - 1995-Cornish, Poon (-)

- Central Queensland University (CQU) - 2000- Hovenga (1)

- Curtin-1987, 1996, 2002-Galliers, Pervan, Lloyd, Chang (3)

- Deakin-2000, 2002 - P. A. Swatman, Corbitt, Castleman, Warren (2)

- Edith Cowan University (ECU) - 1997-Burn, Standing (1)

- $\quad$ Flinders (-)

- Griffith - 1993 - Cecez-Kezmanovic, Davies, Gammack, Eklund (1)

- James Cook (-)

- La Trobe (-)

- Macquarie - 1995, 1997, 1998- Jordan, Johnson, Offen (3)

- Melbourne-1996, 1997, 2000-Vitale, Morrison, Sonenberg, Ferguson, Shanks (3)

- Melbourne Graduate School of Management - 1993, 1999-Vitale, Weill (-) 
- Monash—1990, 1990, 1990- $\underline{\text { Arnott, Steele, Juliff, Dooley, Shanks, Weber }}$ (3)

- Murdoch (-)

- Newcastle-2000 - Aisbett (1)

- University of New England (UNE) (-)

- UNSW-1974, 1990, 1991-Brookes, Jeffery, Lawrence, Low, Cavaye, Cecez-Kezmanovic (4)

- Notre Dame-2000 - Glasson (-)

- Queensland-1981, 1990-Weber, Orlowska, Green (2)

- QUT-1993, 1999-Papazoglou, Gable, Underwood, Rosemann (2)

- Royal Melbourne Institute of Technology (RMIT) - 2003, 2007-Swatman,

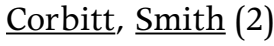

- University of South Australia (UniSA)-2002, 2003, 2003- Koronios, Swatman, Swatman (3)

- Southern Cross University (SCU) - 2000 - Cavaye, Murugesan (1)

- University of Southern Queensland (USQ) - 2007- Toleman (1)

- Sunshine Coast-2003- Fitzgerald (1)

- Swinburne-2000 - Grant (1)

- Sydney-1998, 2002, 2002- - Patrick, Elliot, O'Connor (3)

- Tasmania 1992, 1999-Leech, Keen, Marshall, Lueg (2)

- UTS - 1990, 1998- Hawryszkiewycz, Henderson-Sellers (2)

- Victoria University (VU) -2002, 2002- McGrath, Zeleznikow (2)

- University of Western Australia (UWA) (-)

- University of Western Sydney (UWS) - 1998 - Cecez-Kezmanovic (-)

- Wollongong - 1988, 1994- Gaffikin, Winley, Eklund (2)

\section{List by person}

Underlining indicates that the appointment was current in early 2007.

- Janet AISBETT (NO) - Newcastle, 2000?-

- David ARNOTT [7] (NO)- Monash, 1990-

- Cyril BROOKES [1] (NO)-UNSW 1974-94

- Janice BURN (D)—ECU, 1997-2005?

- Tanya CASTLEMAN (D)- Deakin, 2002-

- Angele CAVAYE (D) - SCU 2000-02?, UNSW, 2002?-

- Dubravka CECEZ-KEZMANOVIC(D)—Griffith, 1993-97?, UWS 1998?-2002?, UNSW 2002?-

- Elizabeth CHANG (NO) Curtin, 2002?-

- Brian CORBITT (NO)-Victoria University of Wellington 1998?-2000?, Deakin 2000?-2003?, RMIT, 2003?-

- Brian CORNISH (NO) - CSU, 1995?-2000?

- Lynda DAVIES (NO) -Griffith, 1995?-2000?

- Laurence DOOLEY (D)- Monash, 2000?- 
- Peter EKLUND (D) - Griffith 1998-2002, Wollongong, 2004-

- Steve ELLIOT (NO)- Sydney, 2002?-

- Colin FERGUSON (D)- Melbourne, 2004-

- Gavin FINNIE (NO) - Bond, 2005-

- Ed FITZGERALD (D) - Sunshine Coast, 2003-

- Guy GABLE (D) - QUT, 1999-

- Michael GAFFIKIN (D)-Wollongong, 1988 (accountancy)-

- Bob GALLIERS [3] (NO)—WAIT/Curtin, 1987-88

- John GAMMACK (D) - Griffith, 2000-

- Bernie GLASSON (D)—Notre Dame, 2000-03?

- Ashley GOLDSWORTHY (NO)—Bond, 1994?-99?

- Doug GRANT (D)- Swinburne, 2000?-

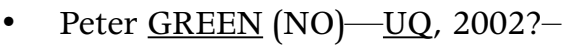

- Shirley GREGOR (D)- $\underline{\mathrm{ANU}}, 2001-$

- Igor HAWRYSZKIEWYCZ [6] (NO)- UTS, 1990-

- John HAYNES (NO) - $\underline{\text { CDU }}, 2005$ ?-

- Brian HENDERSON-SELLERS (NO)-UTS, 1998?-

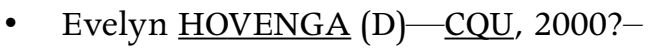

- Ross JEFFERY [4] (NO)- UNSW, 1990-

- Michael JOHNSON (D)- Macquarie, 1997?-

- Ernest JORDAN (D) - Macquarie, 1998?-

- Peter JULIFF [7] (NO)-Monash, 1990-97?

- Chris KEEN (NO)-Tasmania, 1999-2007

- Andy KORONIOS (D)- UniSA, 2002-

- Michael LAWRENCE [10] (NO)-UNSW, 1991-2004?

- Stewart LEECH [11] (NO)-Tasmania, 1992-2000, Melbourne, 2000-

- Ashley LLOYD (NO) Curtin, 2002-

- Christopher LUEG (D) - CDU, 2004-05, Tasmania, 2005-

- Graham LOW (D) -UNSW, 1998?-

- Michael McGRATH (D)—VU, 2002-

- Peter MARSHALL (D)-Tasmania, 2001-

- Iain MORRISON (NO)-Melbourne, 1997?-2003?, Bond 2003?-

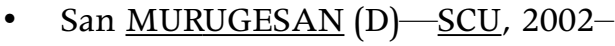

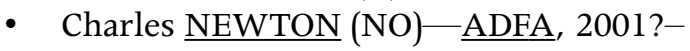

- Marcus O'CONNOR (NO)-Sydney, 2002?-

- Raymond OFFEN (NO)- Macquarie, 1995?-

- Maria ORLOWSKA [5] (NO)- UQ, 1990-

- Mike PAPAZOGLOU (NO)—QUT, 1993?-99?

- Jon PATRICK (D)- Sydney, 1998-

- Graham PERVAN (NO) Curtin, 1996-

- Simpson POON (D) - CSU, 2001?-04?

- Michael ROSEMANN (D)- $\underline{\text { QUT, }}, 2004-$ 
- Graeme $\underline{\text { SHANKS }}$ (NO)-Monash, 2003-06, Melbourne 2006-

- Ross $\underline{\text { SMITH }}$ (D) - $\underline{\text { RMIT, }}, 2007-$

- Liz SONENBERG (D)- Melbourne, 2001?-

- Craig STANDING (D)-ECU, 2003?-

- Phillip STEELE [7] (NO)—Monash, 1990-2001?

- Paul A. SWATMAN (NO)-Deakin 1997-2000, SIMT in Germany, 2000-03, UniSA, 2003-

- Paula M. C. SWATMAN (D)-RMIT 1998-2000, Koblenz 2000-03, UniSA, 2004-

- Mark TOLEMAN (NO) - USQ 2007-

- $\quad$ Alan UNDERWOOD (D)-QUT, 2004-06

- Michael VITALE (D)-Melbourne, 1996-99?, MGSM 1999?-2001?, AGSM, 2001?-

- Matthew WARREN (NO) - Deakin, 2004-

- Ron WEBER [2] (D)-UQ 1981-2004, Monash 2004-

- Peter WEILL (NO)-MGSM, 1993-2002?, MIT 2002?-

- Graham WINLEY (NO)—Wollongong, 1994-2002

- Philip YETTON (NO) -AGSM, 1993-2006

- John ZELEZNIKOW (D)- $\underline{\text { VU, }}$, 2002-

\section{Appendix 2.2: Early Australian PhDs in IS}

This appendix lists Australians known to have been awarded PhDs before the end of 1995, whose work was clearly in or directly relevant to IS. Sources used include the ISWorld Dissertation Database, the Australian Digital Theses Program, the author's memory, interviews with Ron Weber and Cyril Brookes and e-mail discussions with several other people.

This list excludes people who entered the IS discipline with doctorates in other areas, and those who migrated to Australia after completing a doctorate elsewhere. 1977 Ron Weber: Auditor decision making: a study of some aspects of accuracy and consensus and the usefulness of a simulation decision aid for assessing overall system reliability, University of Minnesota, supervisor Gordon Davis.

1982 Errol Iselin: [re information overload], University of Queensland, supervisor Ron Weber.

1984 Iris Vessey: [re psychological processes underlying program debugging], University of Queensland, supervisor Ron Weber.

1986 Ross Jeffery: A comparison of models describing third and fourth generation software development environments, with implications for effective management, University of New South Wales, supervisor Cyril Brookes. 
1987 Rick Watson: A study of group decision support system use in three and four-person groups for a preference allocation decision', University of Minnesota, supervisor Gerry DeSanctis.

1987 Bob Galliers: Information systems planning in Britain and Australia in the mid 1980s: key success factors, London School of Economics, supervisor Frank Land.

1988 Peter Clayton: User involvement in academic library strategic planning: congruence amongst students, academic staff and library staff at the Canberra College of Advanced Education [very close to IS!], University of Canberra, supervisor unknown.

1989 Patricia Willard: The personal computer and the public library: a study of the absorption of new technology and an analysis of librarians' opinions about the present and future impact on Australian public libraries [very close to IS!], University of New South Wales, supervisor unknown.

1990 Marianne Broadbent: The alignment of business and information strategies', Graduate School of Management, University of Melbourne, supervisor Peter Weill.

1992 Chris Sauer: Information systems failure: the problem of managing support for a flawed innovation process, University of Western Australia, supervisor unknown.

1992 Paul Swatman: Increasing formality in the specification of high quality information systems in a commercial context, Curtin University of Technology, supervisor Roger Duke.

1993 Paula Swatman: Integrating electronic data interchange with existing organisational structure and internal application systems: the Australian experience, Curtin University of Technology.

1994 James Popple: SHYSTER: a pragmatic legal expert system, The Australian National University, supervisor Roger Clarke.

1994 Graham Pervan: A comprehensive model of group support systems application: development and initial testing, Curtin University of Technology.

The year 1995 was selected as the cut-off point on the pragmatic grounds that the numbers increased significantly from then onwards, with at least seven $\mathrm{PhDs}$ in 1996 (D'Ambra, Gould, Gregor, Green, Kirlidog, Mackay and Sayer) and at least five in 1997 (Clarke, Klobas, Parker, Shanks and Williams). It would appear that, by 2002, about 20-30 IS PhDs were graduating from Australian universities each year (Pervan and Shanks 2004). 


\section{Appendix 2.3: The early international impact of Australian IS}

This appendix reports the results of a brief analysis undertaken of the international impact of Australian IS scholars.

The period considered is limited to 1965-95. The measures used have been limited to publications in the discipline's flagship journals and conferences.

The following people have been excluded, because their work during the relevant period was undertaken elsewhere or they were only visiting: Janice Burn, Angele Cavaye, Philip Ein-Dor, Bob Galliers and Michael Vitale.

The first specialist journal, MIS Quarterly, has been published since 1977. Authorship was strongly American during its first two decades. The first Australian author appears to have been Iris Vessey, in June 1980 (vol. 4, no. 2) and again in June 1981 (vol. 5, no. 2). (She could also have been the first non-American author and/or the first non-American $\mathrm{PhD}$ to publish there.) Ted Stohr followed in December 1983 (vol. 7, no. 4). Vessey published again in March 1988 (vol. 12, no. 1), this time in conjunction with Peter Tait of Touche Ross, Brisbane. Rick Watson appeared for the first time in September 1988 (vol. 12, no. 3), Eric J. Walton (then at UWA) in December 1988 (vol. 12, no. 4), Peter Weill in March 1989 (vol. 13, no. 1), Watson again in June 1990 (vol. 14, no. 2), Michael Lawrence and Graham Low from UNSW in June 1993 (vol. 17, no. 2), and Watson again in June 1995 (vol. 19, no. 2). Tellingly perhaps, Ron Weber appears only as an editor - and only from 2002.

In Information \& Management, the first paper by an Australian was by Ross Jeffery and Iris Vessey in 1980, the next by Ross Jeffery and Michael Lawrence in 1981, then Bob Edmundson and Ross Jeffery in 1984, Vessey again in 1986, Michael Sager in 1988, Bill Cundiff in 1989 and then Guy Gable in 1991.

Information Systems Research (ISR) was a relative late comer on the journal scene - in 1989. Australians were slow to break into it as well, with the first published appearing to be Iris Vessey in 1995 (vol. 6), Ron Weber twice in 1996 and Peter Seddon in 1997.

Brisk analysis of the early years in Management Science identified no papers before 1996 (vol. 42), when Ron Weber and Guy Gable published. Rick Watson published there in 1998.

Communications of the ACM was an outlet for quality refereed articles in IS from the late 1970s until it adopted a lower-quality magazine format in the early 1990s. Early Australian IS authors were Iris Vessey and Ron Weber in February 1983 (vol. 26, no. 2) and again in January 1986 (vol. 29, no. 1), Ron Weber in January 1988 (vol. 31, no. 1) and Roger Clarke in May 1988 (vol. 31, no. 5). 
The first ICIS Proceedings in 1980 included a paper by Ted Stohr (already of NYU); although the 'I' stands for 'international', the first ICIS was addressed exclusively by people resident in the United States. The 1981 proceedings included six papers with non-American authors (from the Netherlands, Belgium, Canada and Israel); 1982 included a similar number, with Finland, Sweden, Israel, Canada and Singapore represented; 1983 was similar, but Norway and Italy made their first appearance, and Ted Stohr again contributed.

The first contributions from Australia were in 1985: by Iris Vessey and Ron Weber and by Vessey as sole author (both at that stage were at the University of Queensland); and by Rick Watson, then of the West Australian CAE. Weber reappeared in 1988. In 1989, Australia was represented by Weber, Peter Creasy (also of the University of Queensland) and Peter Weill (at that stage of the University of Melbourne). Rick Watson appeared in 1989, although by then he was at Georgia. In 1990, Weber appeared again, as did Weill and Marianne Broadbent. In 1991, Weber (twice), Weill and Broadbent, and Watson again featured, and Paula and Paul Swatman made their first appearance. The steady increase in competition for space has meant that Australian representation on the ICIS program, although consistent, has seldom been as high since then. It did include the Best Paper Award in 1996-awarded to Broadbent and Weill (with two non-Australian co-authors).

The ECIS conference has also had high standards since it began in 1993, and the involvement of Australians has been considerable. Galliers and Whitley note that, in the first 10 years (1993-2002), '[T]he UK [had] by far the largest proportion of papers [398, 24 per cent], the second largest contributors [being] Australia (153, 9 per cent] and the USA [143, 9 per cent, ahead of Germany 134, 8 per cent and the Netherlands 103, 6 per cent].'

In summary, by 1995, it appears that only two resident Australians had published in MIS Quarterly, Management Science and Information Systems Research combined, and only a further three in Information \& Management and two in Communications of the ACM. Moreover, Walstrom and Leonard's (2000) 'Citation classics' article did not appear to include any contributions by Australians (although of course the same can be said for most countries, as the research arena has been dominated so heavily by US academics). On a proportional basis, Australians did not figure strongly in the early years of the discipline, but a small number of individuals forged substantial international reputations.

In more recent years, Australians have been well represented in international conferences, particularly in Europe and to a lesser extent in North America. Their impact in major journals continues to be swamped, however, because of the large and in part very professional population of American, and to a lesser extent Canadian and European, IS researchers. The United Kingdom is probably the next most influential country, after which Australia can probably claim its 
place - at worst on a per capita par with Hong Kong and Singapore, and with the Netherlands and Germany. Many countries in Europe, Asia and South America are, of course, held back by the very strong English-language bias in the IS discipline.

\section{Acknowledgements}

\section{Acknowledgement of bias}

The author has been active in the IS discipline since 1970 - that is to say, not from the very beginning, but from very shortly afterwards. Because the author was a contemporaneous observer of many of the phases that the chapter deals with - and often a participant and even a protagonist - his perspectives are inevitably embedded in the analysis. In addition, the author is not a trained historian. For these reasons, the chapter is entitled 'a retrospective' rather than 'a history'. It has, however, drawn on a wide variety of sources and will hopefully make a contribution to an emergent 'court history' of the discipline.

An attempt has been made to present information dispassionately; the degree to which that could be achieved is qualified, however, due partly to the author's inherent and unavoidable biases, but partly because of the conflicting aim of achieving at least some degree of readability and stimulation.

\section{Acknowledgements of others}

My thanks to Guy Gable and Bob Smyth for providing the stimulus for this chapter, and for the important inputs provided by them and other members of the IS-in-Oz project team.

The chapter has benefited greatly from interviews with the following key players in IS in Australia, listed in alphabetical order: Cyril Brookes, Bill Caelli, Frank Land, Stewart Leech, Gerry Maynard, Graham Pervan and Ron Weber. Many other senior members of the discipline made important contributions, including Dick Mason, Ann Moffatt, Phillip Ein-Dor, Iris Vessey and Bob Galliers. In relation to the PIT scheme, my thanks to Gerry Maynard, John Austin, John Growder, Rob Thomsett, Jonathan Palmer and Kerry Webb.

Responsibility for the errors, the omissions, the unfortunate phrasings and the judgementally impregnated expressions rests with the author. The electronic version of the chapter is intended to be a living document for a while at least, and suggestions for improvement of all kinds should be submitted to the author. It is intended that this chapter and the supporting documents will be mirrored on appropriate web sites. A living version of this document is available at http://www.anu.edu.au/people/Roger.Clarke/SOS/AISHist.html 


\section{Vale Cyril Brookes}

As this chapter was going to press, word arrived of the death by accident of Cyril Brookes. Among many other things, Brookes was the first Professor of Information Systems in Australia — at UNSW from 1974 to 1994. It would appear that he is the first Australian professor of IS to pass on.

Brookes became the Founding Professor of Information Systems at UNSW in 1974 after a distinguished decade with BHP, culminating in his role there as Manager, Corporate Data Processing. The IT faculty grew to be one of the largest in Australia, with 30 academics and 1000 students during his 20-year tenure. His practical experience and professional determination to reinforce technological alignment with business and government supported the university's drive into cooperative education schemes with industry. He was involved as well in the design of advanced computer-based production systems, the work later leading to his establishing grapeVINE and BI Pathfinder as successful commercial enterprises. Brookes also worked to promote sound governance of ICT in Australia; he was NSW chair of the ACS, an executive committee member for several years and he served on IFIP's IS committee for a decade from 1975. He was made an ACS Fellow in 1972, and was founding director and later chair of the Australian Association of Chief Information Officers. His contribution to IS in Australian universities was massive. His untimely passing is lamented greatly. 